\title{
Reforming vehicle taxes on new car purchases can reduce road transport emissions - ex post evidence.
}

\section{Anna Mortimore *}

\section{Abstract}

Australia is falling behind the international trend towards low carbon transport to reduce greenhouse gas (GHG) emissions. For instance, in 2012 the Australian Government forecasts that road transport emissions will continue to increase to 2020 and then slow to 2030 because of higher oil prices and the introduction of mandatory $\mathrm{CO} 2$ emissions standards. The forecast assumes vehicle efficiencies of petrol and diesel engines will improve, and there will be a gradual shift to alternative technologies. However, in 2007 the European Union found that while advances in

* $\quad$ Lecturer - Taxation, Griffith Business School, Griffith University, Gold Coast, Queensland. Anna is enrolled in a doctoral program at Macquarie University's Faculty of Business and Economics. Email: a.mortimore@griffith.edu.au. 
vehicle technology had delivered most of the carbon reductions, these advances were offset by new cars that had become significantly more powerful, larger, and heavier. This is the case in Australia. The paper shows how Australia can accelerate the uptake of low carbon technology through reforming existing vehicle taxes into an environmental related tax. The reform will require basing the tax on $C 02$ emissions from previously being based on the vehicles technical characteristics such as cylinder capacity, engine size and fuel type. The literature supports the reform of vehicle taxes into an environmental tax, which was found to be a powerful instrument in influencing the purchase decisions of consumers. ${ }^{1}$ Specifically, the paper examines the literature and reviews the ex post evidence on the successful reform of vehicles taxes. In the case study of Ireland, it was found that the reformed vehicle taxes based on $\mathrm{CO} 2$ emissions provided a strong price signal, and consumer response was greater than anticipated. As a result, Irelands ambitious targets in reducing its GHG emissions were met. ${ }^{2}$ The paper provides evidence to Australia's policy makers, consultants and car manufacturers that reforming existing vehicle taxes into an environmental related tax is an effective measure in transitioning Australia into a low carbon transport and reducing road transport emissions.

1 European Commission, Communications from the Commission to the Council and the European Parliament: "Results of the review of the Community Strategy to reduce $\mathrm{CO} 2$ emissions from passenger cars and light-commercial vehicles", (SEC) Brussels, February 2007.

2 Fionn Rogan et al., "Impacts of an emission based private car taxation policy- first year ex-post analysis” (2011) 45 Transportation Research Part A: Policy and Practice 583, 596. 


\section{Introduction}

The transport sector is arguably the most difficult and expensive sector in which to reduce greenhouse gas emissions $(\mathrm{GHG}),{ }^{3}$ with carbon dioxide $(\mathrm{CO} 2)$ generated by transport in Australia increasing by 50.7 percent (93.5 Mt CO2-e) in 2012-2013 from 1990 levels (62.0 Mt CO2-e). ${ }^{4}$ Unless the government reverses this trend, CO2 emissions will continue to rise and offset the gains made in reducing carbon emissions in other energy sectors. ${ }^{5}$ The largest contributor to transport GHG emissions is road transport. The International Energy Agency states that to limit emissions from this sector, policy makers should implement measures to encourage a shift from cars to public transportation and to fuel efficient and lower carbon vehicles. ${ }^{6}$ The scope of this paper addresses policy measures that encourage a shift to such lower carbon motor vehicles.

In 2010, the Henry Report stated that greenhouse gas emissions was best dealt with through an economy-wide market mechanism or similar scheme, and once they were in place it would be inefficient to impose taxes on transport or fuel. ${ }^{7}$ However, the proposed market mechanism entitled Carbon Pollution Reduction Scheme was not passed through the Senate, and the proposed mechanism was deferred in 2010. Nonetheless, a carbon tax under the Clean Energy Act 2011 was introduced on 1 July $2012^{8}$. However, transport fuel for light vehicles was exempted from the carbon tax because it was met with strong opposition from consumers and did not receive

3 Transport Policies to reduce CO2 Emissions from the light Duty Vehicle Fleet," in Raymond Kopp and William Pizer (eds.), Assessing U.S. Climate Policy Options (Resources for the Future, Washington:2007).

4 Australian Government, Australian National Greenhouse, "Quarterly Update of Australia’s National Greenhouse Gas Inventory June Quarterly 2013 Update of Australia’s National Greenhouse Gas Inventory" http://www.environment.gov.au/system/files/resources/ef4a14b19ec8-48d5-b776-70a3795c7bfc/files/quarterly-update-june-2013.pdf, 8

5 Department of Climate Change and Energy Efficiency, "Reducing Carbon: Reducing Australia's Emissions" (2012) http://www.climatechange.gov.au/climate-change/greenhouse-gasmeasurement-and-reporting/australias-emissions-projections/national at 27 March 2013.

6 France, International Energy Agency, "CO2 Emissions from Fuel Combustion 2012" <http:// www.iea.org/publications/freepublications/publication/CO2emissionfromfuelcombustionHIG HLIGHTS.pdf $>$ at 1 July 2013, 10.

7 Australia, Australian Government, "Australia’s future tax system: Report to the Treasurer", Canberra, Henry Tax Review, December 2009, 389.

8 Australia, Australian Government, "Securing a Clean Energy Future, The Australian Government's Climate Change Plan" 2011< http://www.cleanenergyfuture.gov.au/wp-content/ uploads/2011/07/Consolidated-Final.pdf> para 3.2.1 at 21 February 2013. 
public support. ${ }^{9}$ Rabe $(2012)^{10}$ found perceived benefits of including transport fuel in a carbon tax may be difficult to discern and not calculable until future generations. Anable, Lane and Kelay (2006) ${ }^{11}$ stated that the UK survey indicates that level of support for government action diminishes significantly with respect to policies to tackle emissions from transport.

The Australian Government has since then introduced no other fiscal instrument. Nor did the 2012 Energy White Paper entitled Australia's Energy Transformation ${ }^{12}$ set any short and long-term targets to encourage a shift to fuel-efficient and lower carbon vehicles. Clearly, this failure to address road transport emissions makes it challenging for Australia to reach its global obligation to reduce the country's GHG emissions.

Hence, it is argued that rising road transport emissions can be addressed through reforming existing vehicle taxes into an environmental related tax. It is also argued that reformed vehicle taxes will receive public acceptance, because they are founded on an existing tax, will only apply to the acquisition of new vehicles, and will not receive the political backlash of introducing a new tax.

The earlier literature on the effectiveness of reforming vehicles taxes on the basis of $\mathrm{CO} 2$ emissions has been mixed. However, an ex post analysis of the policy change in the European Union indicates that the success of the differentiated $\mathrm{CO} 2$ vehicle taxes aimed at reducing $\mathrm{CO} 2$ emissions will depend on the design of the tax and the rate of tax differentiation in providing a strong price signal to influence the decisions of consumers to purchase fuel efficient and lower carbon motor vehicles. ${ }^{13}$ It was found to be a "powerful instrument" that could achieve environment goals (reduce carbon emissions), economic policy goals (vehicle taxation revenue and vehicle ownership levels), ${ }^{14}$ and social policy goals (influence car purchase behavior, maintain public acceptance and equity). ${ }^{15}$ Depending on the design of the tax, it could control vehicle

9 Phillip Coorey, "Windsor says he'll stop carbon plans if Greens go too far", The Sydney Morning Herald (Fairfax Media), 28 February 2011. It was considered inequitable to penalize people for living in rural areas by imposing a carbon tax on fuel, when there was no access to public transport in these areas and no alternative but to use private vehicles for transport

10 Barry Rabe and Christopher Borick, "Carbon Taxation and Policy Labelling: Experience from American States and Provinces" (2012) 29 Review of Policy Research 3, 358.

11 United Kingdom, UK Department for Transport, "An evidence base review of public attitudes to climate change and transport behaviour" (Jillian Anable, Ben Lane and Tanika Kelay) July 2006.

12 Australian Government, Department of Industry, "2012 Energy White Paper: Australia's energy transformation” <http://www.ret.gov.au/energy/facts/white_paper/Pages/energy_ white_paper.aspx\#what> at September 2013.

13 Ibid para 3.3.8

14 Christian Brand, Jillian Anable and Martino Tran, "Accelerating the transformation to a low carbon passenger transport system: The role of car purchase taxes and scrappage incentives in the UK” (2013) 49 Transportation Research part A 132.

Ibid. 
ownership, vehicle engine efficiency, and the development of new technology. ${ }^{16}$ Furthermore, reformed vehicle taxes could indirectly provide a non-tariff barrier that would discourage the importation of high polluting vehicles into the importing country. ${ }^{17}$

In the context of reducing carbon emissions of new light motor vehicles, this paper first examines the importance of setting environmental policy objectives and targets in formulating policy design. Second, the paper assesses Australia's progress in transitioning new motor vehicle fleet to low carbon transport. Third, the paper examines whether Australia ought to adopt environmental tax reform of its vehicle taxes by differentiating such taxes on the basis of carbon emissions, and whether it can also become a "powerful instrument" in accelerating the transition of Australia's new motor vehicles to a low carbon passenger fleet. A case study of Ireland's effective reform of its vehicle taxes for its passenger fleet in 2008 is examined, because of its similarity with Australia's growing trend for large, high-polluting vehicles and significant growth in road transport emissions. This paper provides support for Australian policy makers that reforming existing vehicle taxes into an environmentally related tax, can be effective in reducing road transport emissions by providing a strong price signal that will influence buyers into choosing fuel efficient and lower carbon emitting light vehicles.

\section{Australia's future projections for road transport emissions}

In ratifying the Kyoto Protocol to the United Nations in December 2007, the Australian Government committed unconditionally to reduce its emissions by 5 percent and conditionally by 15 or 25 percent of 2000 levels by 2020 , depending on the extent of international action. ${ }^{18}$

The transport sector in Australia is the second largest source of GHG emissions, ${ }^{19}$ and reducing emissions in this sector plays an important role in this country's international obligation to meet the above emission target. However, annual emissions from transport increased by 2.8 percent in the year to June 2013, and offset the

16 Heinz Jansen, Cecile Denis, (1999) "Welfare cost assessment of various policy measures to reduce pollutant emissions from passenger road vehicles" 4 Transportation Research: Part D: Transport and Environment 379.

17 Eri Saikawa, "Policy Diffusion of Emission Standards, Is there a Race to the Top ?" (2013) 65 World Politics 1.

18 Australian Government, Department of the Environment, "Reducing Carbon National Targets: December 2007” <http://www.climatechange.gov.au/climate-change/greenhouse-gasmeasurement-and-reporting/australias-emissions-projections/national > at 15 September 2013.

19 Australian Government Department of Environment, "National Greenhouse Gas Inventory June Quarter 2013" < http://www.climatechange.gov.au/sites/climatechange/files/ documents/03_2013/nggi-quarterly-2010-dec.pdf> at 29/1/2014, para 3 
decline of emissions in other sectors to a total reduction of the country's emission by 0.1 percent. $^{20}$

Unless this trend towards rising transport emissions can be reversed, the Australian Government will find it challenging to reach the above commitments. Hence, the Australian Government cannot ignore the challenge to abate transport sector emissions if it is to meet its international obligation to reduce the country's emissions.

\subsection{Projected growth in transport emissions}

In 2012, the transport sector contributed 15 percent (91 MtCO2-e) of Australia's net emissions, and is the second largest source of emissions growth in Australia. ${ }^{21}$

Table 1: Projected growth of transport emissions

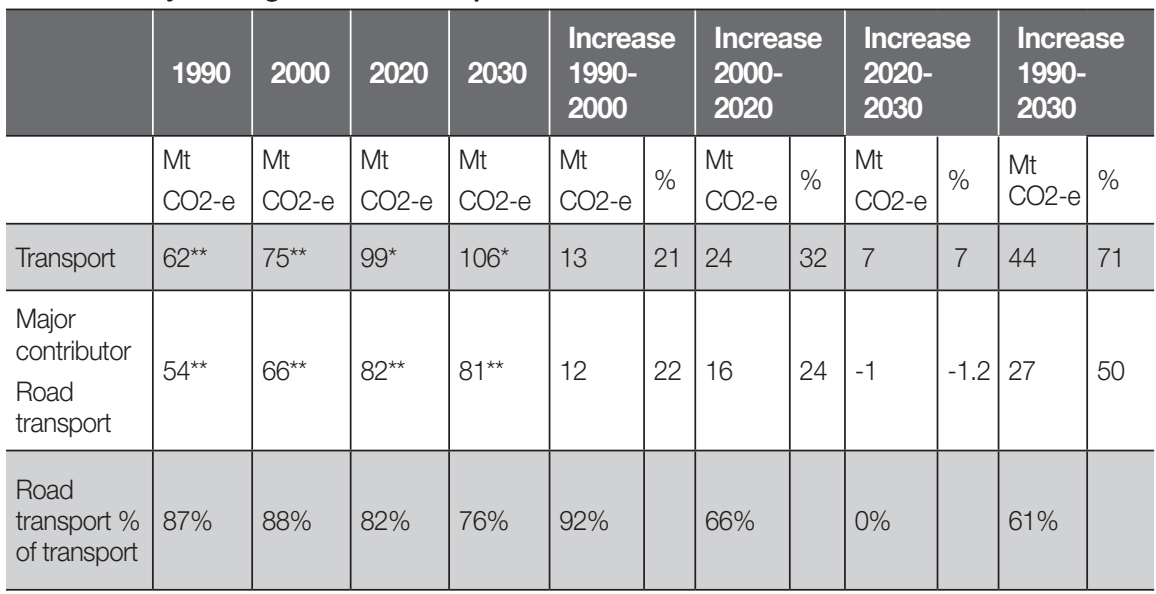

Source: ${ }^{\star}$ Australian Government: Department of the Environment Australia, 'Australia's Abatement Task and 2013 Emissions Projections.'

**Australian Government: Department of Climate Change and Energy Efficiency, 'Australia’s Emissions Projections 2012' http://www.climatechange.gov.au/sites/climatechange/files/files/ climate-change/projections/aep-summary.pdf, 1990: Table 4, 6; 2000: Table 4,6; 2020: Table 5, 7; 2030: Table 6, 8 .

20 Australian Government, above n 4.,3.

21 Australian Government: Department of the Environment. "Australia's Abatement Task and 2013 Emissions Projections", http://www.environment.gov.au/node/35053 at 30 January 2014, 11 
From 1990 to 2012, emissions from the transport sector increased by 50.7 percent to 93.5 Mt CO2-e $\mathrm{e}^{22}$, and are projected to increase to 59.6 percent of 1990 levels by 2020 (99 Mt CO2-e), and 70.9 percent of 1990 levels by 2030 (106 Mt CO2-e).

The transport sector in Australia is the largest user of final energy, and accounted for 73 percent of total final consumption ${ }^{23}$ in May 2013. Automotive gasoline accounted for 41 percent of total energy use in the sector. ${ }^{24}$ The challenge for Australia, then, is to reduce emissions from the transport sector given that it is entirely dependent on fossil fuels. ${ }^{25,26}$

As shown in Table 1, road transport is the largest subsector in the transport emissions, which accounted for 87 percent of transport emissions in 1990, and projected to reduce to 82 percent of transport emissions by 2020 and 76 percent of transport emissions by 2030. However, the 2012 White Paper has forecast that road transport activity will more than double by $2050 .{ }^{27}$

Table 1 shows that the Australian Government is projecting future growth in road transport emissions of 24 per cent in the period 2000 to 2020. It is also projecting that this will then slow to no growth in the period between 2020 and 2030 because of a combination of ongoing vehicle efficiency improvements and the adoption of new technologies. ${ }^{28}$

Vehicle fuel efficiency improvements will include a "substantial fuel substitution" from petrol to diesel and biodiesel, ${ }^{29}$ a gradual increase in the adoption of hybrid vehicles, and the emergence of electric road vehicles which will become more cost competitive with conventional internal combustion engine vehicles. ${ }^{30}$ It is projected that the gradual adoption of such vehicles will be a "result of the time taken to turn over the existing vehicle fleet". ${ }^{31}$ It is also anticipated that there will be a shift in

22 Australian Government, above n 4, 9.

23 Australia, Australian Government: Department of Resources, Energy and Tourism, Economics, Energy in Australia May 2013 http://bree.slicedlabs.com.au/sites/default/files/files/ publications/energy-in-aust/bree-energyinaustralia-2013.pdf at 30 January 2013, 73

24 Ibid 73.

25 Ella Graham-Rowe et al., "Can we reduce car use and, if so, how? A review of available evidence" (2011) 45 Transportation Research Part A: Policy and Practice 401.

26 Pascal Poudenx, "The effect of transportation policies on energy consumption and greenhouse gas emission from urban passenger transportation” (2008) 42 Transportation Research Part A: Policy and Practice 901.

27 Australia, Australian Government: Department of Energy, Resources and Tourism, "2012 Energy White", above n 12 para 3.3.8.:35

28 Australia, Australian Government: Department of Industry, Innovation, Climate Change, Science, Research and Tertiary Education, "Australia's Emissions Projections 2012" < http:// www.climatechange.gov.au/reducing-carbon/reducing-australias-emissions/australiasemissions-projections> at 2 February 2014, 13.

29 Ibid, 7.

30 Ibid 12.

31 Ibid 12 
private road transport towards smaller vehicles that are more fuel economical than medium and large passenger vehicles. ${ }^{32}$

As the 2012 Energy White Paper ${ }^{33}$ noted, “...increased fuel efficiency will be essential if emissions are to be reduced [and] innovation and better urban planning will also play important roles." ${ }^{34}$ The 2012 Energy Paper also pointed to higher fuel prices and the introduction of mandatory $\mathrm{CO} 2$ emission standards for light vehicles to improve the vehicle efficiencies of conventional internal combustion engines and the transition to electric and hybrid vehicles. ${ }^{35}$

However, the 2012 Energy White Paper also observed that, "success will depend on the ability of these technologies to meet consumer needs". ${ }^{36}$ In effect, the 2012 Energy White Paper assumes consumers will make the gradual transition to alternative technologies such as hybrid, electric and smaller vehicles, without complementary measures such as environmental related taxes to encourage consumers to choose such vehicles.

The European Commission, however, found that the combination of fiscal instruments such as mandating $\mathrm{CO} 2$ emission standards and the environmental tax of higher fuel prices was not enough to transition to lower carbon vehicles and reduce road transport emissions. ${ }^{37}$

Whether there will be a change of approach in the release of the Energy White Paper in late 2014, given the change of government in 2013, is yet to be seen. In December 2013, the Australian Government released an Issues Paper seeking preliminary consultation on "identified issues of interest", which will be addressed in the Government's Energy White Paper. ${ }^{38}$ In terms of reducing transport emissions, the Issues Paper seeks consultation on the same issues addressed in the 2012 White paper, namely the importance of improving fuel efficiency and increasing the use of alternative fuels. ${ }^{39}$ Further, the Issues Paper seeks comments on measures that may encourage changing attitudes and behaviour towards efficient fuel use, as well as the uptake of technology to improve transport energy efficiency. ${ }^{40}$ Moreover, for alternative fuels, the Government seeks comments on any barriers to increasing the uptake of electric vehicles, LPG and advanced biofuels. ${ }^{41}$ The Issues Paper

32 Ibid 13.

33 Australian Government: Department of Resources, Energy and Tourism, "2012 Energy White Paper", above n 12.

34 Ibid para 3.3.8: 35 .

35 Ibid.

36 Ibid. para 3.3.8

37 European Commission, above n 1, para 3.1.

38 Australian Government: Department of Industry, "Energy White Paper, Issues Paper December 2013", http://ewp.industry.gov.au/sites/ewp.industry.gov.au/files/energy-whitepaper-issues-paper_0.pdf, at 3 February 2014, (ii)

39 Ibid.

40 Ibid, 33.

41 Ibid, 38. 
acknowledges the importance of fuel quality standards and fuel economy disclosure to help improve efficiency, ${ }^{42}$ and that there are "opportunities to raise performance standards utilizing existing legislation, with minimum cost to the economy but with an overall benefit to the economy." 43

This paper provides ex-post analysis and evidence that reforming existing legislation, namely vehicle purchase taxes, can satisfy the Issues Paper directive of changing attitudes and behavior by encouraging the uptake of low emission vehicles to improve fuel efficiency and significantly reduce GHG emissions.

\subsection{No future targets to reduce road transport $\mathrm{CO} 2$ emissions}

The Australian Government has no ambitious targets or strong commitment to reducing GHG emissions from road transport. Instead, the Australian Government forecasts that transport emissions will continue to rise as discussed in paragraph 2.1.

In contrast, other OECD countries have set and/or legislated ambitious targets to reduce road emissions. For instance, the emissions reduction target of the European Commission GHG is to reduce transport emissions by 60 percent by 2050 compared to 1990 levels. ${ }^{44}$ The United Kingdom legislated their 2050 target to cut CO2 equivalent emissions by 80 percent from 1990 levels, with the mid-term target of 60 percent by $2030 .{ }^{45}$ To meet the UK 2030 target, 60 percent of new cars will be required to run on electricity ${ }^{46}$

The Australian Capital Territory Minister for the Environment, Climate Change and Water, Mr Corbell, claims that people around Australia have become disenchanted with the lack of real action to address climate change. On 26 October 2010, the ACT government committed to a "strong and ambitious target" of 40 percent cut in emissions based on 1990 levels by 2020, and 80 percent by 2050. As Mr Corbell pointed out, "By passing the Climate Change and Greenhouse Reduction Bill 2010, the ACT is showing the rest of the country what must be done." ${ }^{\prime 4}$

42 Ibid, 32.

43 Ibid, 32.

44 European Commission, "Roadmap to a Single European Transport Area - Towards a competitive and resource efficient transport system 2011" (European Commission) Brussels, March 2011.

45 United Kingdom, UK Committee on Climate Change, "Meeting Carbon Budgets - The Need for a Step Change, Progress Report to Parliament," 2009 http://archive.theccc.org.uk/ aws2/21667\%20CCC\%20Report\%20AW\%20WEB.pdf at September 2013.

46 United Kingdom, UK Committee on Climate Change, Meeting Carbon Budgets UK Committee on Climate Change, "Meeting Carbon Budgets - 3rd Progress Report to Parliament," 2011 < http://www.theccc.org.uk/wp-content/uploads/2011/06/CCC-ProgressReport_Interactive_3.pdf > at September 2013.(UK Committee on Climate Change, 2011)

47 S Corbell, "Greenhouse Gas Emissions Targets Adopted" (2010) Minister for the Environment, Climate Change and Water <http://www.environment.act.gov.au/_data/assets/pdf_ file/0020/207335/Greenhouse_Gas_Legislation_Passes_Media_Release.pdf> at 14 June 2013. 
The above reduction targets are more challenging than those set by the Federal Government, which aims to reduce carbon emissions from 2000 levels, not from 1990 levels as discussed in paragraph 2.1.

Jarvinen et al. (2012) argued that to meet these ambitious targets by 2050 will require significant reduction in carbon emissions, and that these targets are incompatible with simply improving the efficiency of petrol and diesel engines. ${ }^{48}$ Rather, it will require the substitution of the internal combustion engine with alternative power systems. ${ }^{49}$ The Australian Governments 2012 White Paper shows no such commitment.

\subsection{Progress since International Energy Agency Review in 2005}

There has not been much progress since the International Energy Agency's review of Australia in 2005 in terms of reducing transport emissions. The IEA stated that transport was receiving less attention than other sectors, with Australia's current fuel efficiency standards at the lower end of the IEA countries. Given this, the IEA recommended that if the Australian Government wanted to deal with the overall energy efficiency of the economy, it should address transport energy use more forcefully. ${ }^{50}$ Clearly, Australia's lack of effective fiscal measures has contributed to Australia's road transport emissions being one of the highest in the OECD.

\subsubsection{Growth in higher carbon emitting vehicles}

As shown in Table 2, the trend of Australia's new vehicle fleet in the period 2010 to 2013 was not towards fuel efficient and lower carbon emitting vehicles.

48 Justine Jarvinen, Fiona Orton and Tim Nelson, "Electric Vehicles in Australia's National Electricity Market: Energy Market and Policy Implications" (2012) 25 The Electricity Journal 63.

49 Ibid.

50 France, International Energy Agency, "Energy Policies of IEA Countries", Australia 2005 $<$ http://www.iea.org/publications/freepublications/publication/australia2005.pdf $>$ at 14 June 2013,13. 


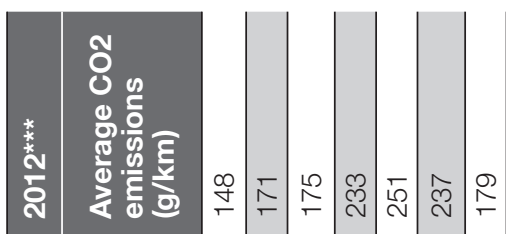

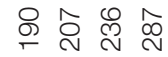

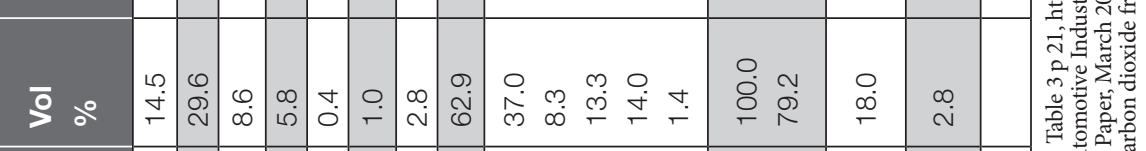

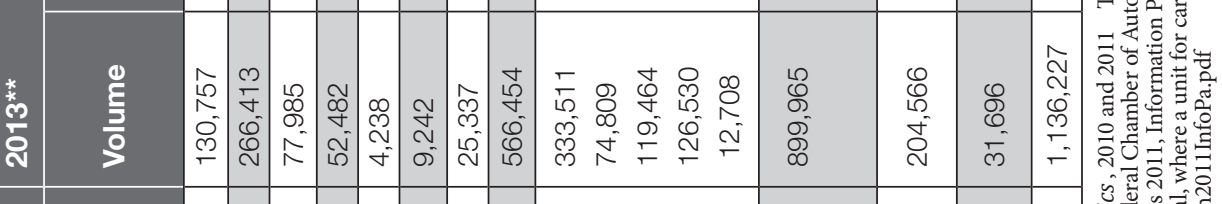

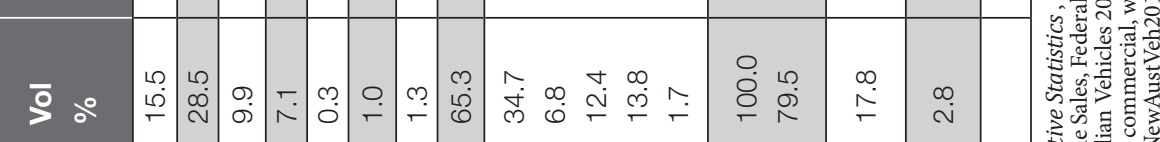

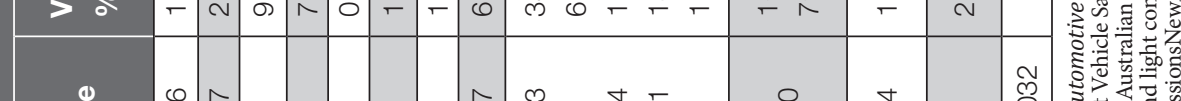

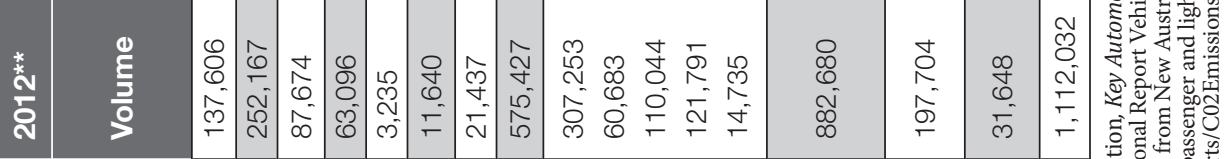

\begin{tabular}{|c|c|c|c|c|c|c|c|c|c|c|c|c|}
\hline$\overline{>}$ ॰ & $\begin{array}{l}\stackrel{\nabla}{\oplus} \\
\stackrel{\sigma}{ }\end{array}$ & $\begin{array}{l}m \\
\dot{\infty}\end{array}$ & $\stackrel{+}{\circ}$ & ڤ் & @ & $\stackrel{n}{\sim}$ & $\stackrel{\infty}{\leftarrow}$ & $\begin{array}{l}\mathscr{0} \\
\stackrel{0}{0}\end{array}$ & $\begin{array}{l}+ \\
\text { ஓं }\end{array}$ & $\begin{array}{ll}\circ & 0 \\
8 & 0 \\
\circ & 0\end{array}$ & $\stackrel{\sim 0}{\stackrel{1}{\Gamma}}$ & $\stackrel{\infty}{\sim}$ \\
\hline
\end{tabular}

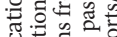

责艺.

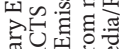

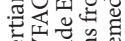

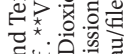

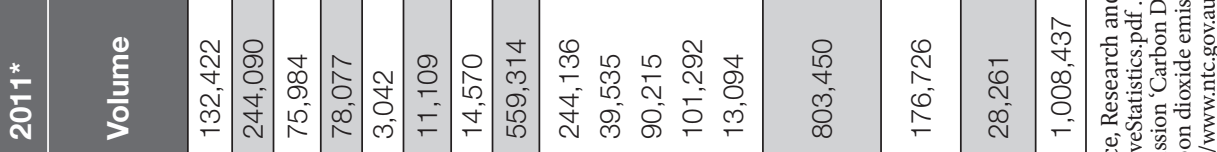

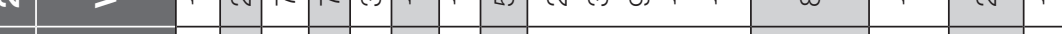

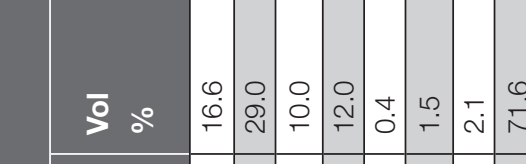

0

*

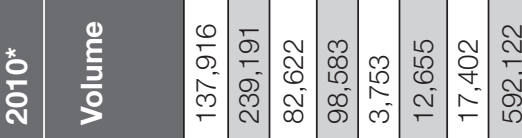


When comparing vehicle sales from 2010 to 2013 for the various vehicle segments in Table 2, the following trends are highlighted: sales of higher carbon emitting SUV's increased by 41 percent in 2013 when compared with 2010; sales of lower carbon emitting light vehicles declined by 5.4 per cent; sales of small vehicles increased by 11.3 per cent; and sales of locally produced high carbon emitting large passenger vehicles declined by 46.7 per cent. Further sales of Australia's locally produced large passenger vehicles as a percentage of passenger and SUV vehicles declined from 12 percent in 2010 to 5.8 percent in 2013.

Overall, Table 2 shows a trend towards higher carbon emitting SUV vehicles rather than a transition to low carbon passenger vehicles. The continuing growth of the high carbon emitting SUV's in Australia's new vehicle sales as shown in Table 2 is in stark contrast to other OECD countries, where market share of large SUVs has decreased. ${ }^{51}$ In the EU, 30.5 percent of total new car registrations in 2011 were passenger cars emitting $101-120 \mathrm{gCO} 2 / \mathrm{km}$, and 67 percent of registrations were vehicles emitting less than $140 \mathrm{~g}$ of $\mathrm{CO} 2 / \mathrm{km}^{.52}$

The continuing growth of SUVs in Table 2 has been described as "Four wheel drives lead car sales to record highs", ${ }^{53}$ "SUVs are the 'fastest growing segment', and as the "SUV phenomenon". ${ }^{54}$ This choice of vehicle by consumers can have a significant impact on $\mathrm{CO} 2$ emissions. For example, on average an SUV produces 70 percent more emissions than a smaller car; ${ }^{55}$ this is discussed further in paragraph 4.1.

In 2007, the European Commission stated that while fuel efficiency increased due to improvements in car technology in the period to 2004, new cars sold in the EU had become significantly bigger and more powerful. ${ }^{56}$

The same trend is occurring in Australia and has contributed to Australia's national average carbon emissions from new passenger vehicles being 46 percent higher

51 France, International Energy Agency, "Tracking Clean Energy Progress 2012" <http://www.iea. org/media/etp/Tracking_Clean_Energy_Progress.pdf > at 2 April 2013.

52 Denmark, European Environment Agency, "Monitoring CO2 Emissions from new passenger cars in the EU: Summary of data for 2011" (European Union) Copenhagen, April 2013.

53 Richard Blackburn, "4WDs lead car sales to record highs", Sydney Morning Herald, 4 January 2013 <http://www.smh.com.au/business/the-economy/4wds-lead-car-sales-to-record-highs20130104-2c850.html> at 6 March 2013.

54 Stephen Ottley, "Soon it will be plug it in not fill it up", Sydney Morning Herald, 26 February $2011<\mathrm{http}$ //smh.drive.com.au/motor-news/soon-it-will-be-plug-it-in-not-fill-it-up20110225-1b8sa.html?utm_medium=twitter\&utm_campaign=DTN+Australia\%3A\&utm_ source=twitterfeed\&utm_medium =twitter\&utm_campaign=DTN+Australia\%3A\&utm_ source $=$ twitterfeed $>$ at 6 March 2013 .

55 United Kingdom, British Government, “The King Review of low-carbon cars Part I: the potential for CO2 reduction 2007" <https://research.mbs.ac.uk/INNOVATION/Portals/0/docs/ seminar/kingreview.pdf> at September 2013.

56 European Commission, above n 1, 6. 
than in the European Union $(199 \mathrm{~g} / \mathrm{km} \text { compared to } 136 \mathrm{~g} / \mathrm{km})^{57}$ in 2012 . Australia's national average carbon emissions from new passenger and light commercial vehicles performance have not improved significantly since the IEA reported on Australia's performance in a 2006 survey of 19 IEA member countries. In this survey, it was reported that Australia had the least efficient road passenger transport and one of the lowest levels of new passenger vehicle fuel efficiency in the world, and that the gap was expected to widen. ${ }^{58}$

Moreover, had Australian consumers purchased vehicles with best-in-class emissions in 2012, the national average carbon dioxide emissions could have been reduced to $119 \mathrm{~g} / \mathrm{km}$, that is, a reduction of 40 percent. ${ }^{59}$ However, with no effective fiscal measures in place, consumers are not encouraged to acquire these best-in-class fuel efficient and lower carbon vehicles.

\subsubsection{Vehicles sold by EU importers have higher average CO2 in}

\section{Australia than in the EU}

The NTC found $\mathrm{CO} 2$ emissions from new vehicles are higher in Australia than in the EU because fewer fiscal measures have been adopted to reduce carbon dioxide emissions. ${ }^{60}$ Further, the absence of strong fiscal measures has allowed unrestricted importation of high carbon emitting vehicles into the Australian new car market. These vehicles would not have sold in the importer's market because high vehicle taxes are imposed and discourage the purchase of less fuel-efficient vehicles, as discussed in paragraph 3. For example, the NTC reports that the average emissions in 2011 for new vehicles by manufacturer for the European Union was at its lowest $119 \mathrm{~g} / \mathrm{km}$ for Fiat, and at its highest $153 \mathrm{~g} / \mathrm{km}$ for Daimler, compared to the average emissions of imported vehicles in Australia which at its lowest was $152 \mathrm{~g} / \mathrm{km}$ for Fiat, and at its highest $227 \mathrm{~g} / \mathrm{km}$ for Volvo. ${ }^{61}$

\subsubsection{Absence of fiscal measures impacts on local car production}

Further, the absence of fiscal measures has allowed the Australian local car industry to become uncompetitive by continuing to manufacture high carbon emitting vehicles, thus limiting car exports to countries without such fiscal measures, such as the Middle East.

57 Australian Government, National Transport Commission, "Carbon Dioxide Emissions from New Australian Vehicles 2012" <http://www.ntc.gov.au/filemedia/Reports/C02EmissionsNewA ustVeh2012InfoPa.pdf> at 14 October 2013.

58 Australian Government Minister's Task Group on Energy Efficiency, "Report of the Prime Minister's Task Group on Energy Efficiency July 2010” <http://ee.ret.gov.au/sites/default/files/ documents/03_2013/report-prime-minister-task-group-energy-efficiency.pdf > at 14 October 2013, 126.

59 National Transport Commission, above n 57, 14.

60 Ibid 25.

61 Ibid 25. 
Economic instruments that directly affect trade have been described as non-tariff barriers because governments restrict imports based on whether the product meets their domestic standards for environmental performance. ${ }^{62}$ Rather than raise the Australian local car industry's environmental standards and bring them into harmony with the stricter standards of their export markets, proponents such as $\mathrm{Mr}$ Weber of the Federal Chamber of Automotive Industries justify the local car industry's position, and argue that Australia needs to "beat down the non tariff barriers across South East Asia for the domestic car industry to remain viable."63

\subsubsection{Importance of fuel economy to rational economic consumers}

The 2012 White Paper claims that consumers will shift to fuel efficient vehicles with higher fuel costs (as discussed in paragraph 2.1) However the findings in the 2002 EU COWI Study discussed in paragraph 3, found rising fuel prices had little effect on people's buying patterns of fuel inefficient, high polluting vehicles,

In terms of buying a car, Greene et al. (2009), ${ }^{64}$ and Anable et al. (2006) ${ }^{65}$ found that up-front vehicle purchase price, reliability, and safety are more important to consumers than environmental concerns. Further, traditional preferences such as appearance, power, image and brand also feature more strongly in consumer's decision making when buying a car. The Australian Bureau of Statistics supports the above findings, given 58 per cent of people considered "purchase cost" to be a key factor when buying a new car in 2012, followed by "fuel economy/running costs" (41 per cent). ${ }^{66}$ Yet, despite public awareness, only 7 per cent of households would consider the "impact on the environment" when choosing a new passenger vehicle. ${ }^{67}$

While fuel consumption is an important factor when choosing a car, consumers take a very short-term view when weighing up vehicle purchase costs, and on average apply a very high discount rate of 60 percent or an equivalent 18 month payback period for fuel costs (The King Review Part I: 2007: 60). ${ }^{68}$ Fisher et al. (2004) ${ }^{69}$ explained that

62 Eri Saikawa, "Policy Diffusion of Emission Standards: Is there a Race to the Top?" (2013) 65 World Politics No 1.

63 Jason Murphy, "Local Auto industry blames FTA with Thailand", Australian Financial Review, 10 April 2013, 3.

64 David Greene, John German and Mark Delucchi, "Fuel Economy: The Case for Market Failure' in James Cannon and Daniel Sperling (eds)", Reducing Climate Impacts in the Transportation Sector (Springer Science and Business Media, Knoxville: 2009).

65 Jillian Anable, Ben Lane and Tanika Kelay, above n 11.

66 Australian Government: Australian Bureau of Statistics, "4102.0 - Australian Social Trends, July 2013”, http://www.abs.gov.au/AUSSTATS/abs@.nsf/Lookup/4102.0Main+Features40July+2 013\#use at 3 February 2014

67 Ibid.

68 David Greene, John German and Mark Delucchi, above n 64.

69 United States of America, "Economic Impacts of Tightening the Corporate Average Fuel Economy (CAFE) Standards" (Carolyn Fisher, Winston Harrington and Ian Parry), Washington, June 2004. 
if consumers fully valued the discounted present value of future fuel savings, then fuel economy standards would largely be redundant. Anable et al. $(2006)^{70}$ found that even if fuel consumption was a first order proxy, its importance 'drops off' nearer to the purchase decision when, as literature suggests, non-environmental factors as discussed above continue to dominate the car purchase process. ${ }^{71}$ Van Dender $(2009)^{72}$ found the problem of low willingness to pay for better fuel economy at least partly stems from consumers' reluctance to pay up front in return for an uncertain reduction in fuel expenditure. Greene et al (2010) makes the following observation:

If consumers undervalue fuel economy improvements relative to their expected present value over the full life of a vehicle, the market will provide too little fuel economy and will under-invest in research and development of energy efficient technologies. ${ }^{73}$

The evidence on consumers' decision making in undervaluing fuel economy is against the rational economic model, and is likely to lead to market failure. ${ }^{74}$ Greene $^{75}$ adds that policies that influence the market via purchase price such as feebates or fuel economy standards have greater leverage on fuel economy than fuel prices. Thus, Greene's views support the European Commission 2002 COWI Study ${ }^{76}$ findings discussed in paragraph 3.2.

Therefore it was critical to provide a strong price signal to ensure the environmental aspect that is factored in when choosing a fuel-efficient, low emitting vehicle does not 'drop-off' at the time of purchase. The European Commission found that reforming existing vehicles taxes differentiated on the basis of carbon emissions is a "powerful instrument" that provides a strong, up front price signal that encourages the acquisition of low carbon vehicles. ${ }^{77}$

It is argued that reforming vehicle taxes into an environmentally related tax differentiated on the basis of carbon emission is critical, given that Australia has no effective environmental policy instrument to accelerate the transition to lower carbon motor vehicles. The 2010 Henry Report's finding that such supplementary measures are not required is no longer applicable,$^{78}$ given that transport fuels for light vehicles (4.5 tonnes or less) are exempt from the carbon tax, as discussed in paragraph 1.0. Fuel tax adjustments were made to heavy vehicles (more than 4.5 tonnes) under the

70 Jillian Anable, Ben Lane and Tanika Kelay, above n 11.

71 Ibid.

72 Kurt van Dender, "Energy Policy in transport and transport policy" (2009) 37 Energy Policy 3854.

73 David Greene, John German and Mark Delucchi, above n 64.

74 Ibid.

75 Ibid

76 European Commission, European Commission's Directorate-General for Environment, "Fiscal Measures to Reduce CO2 Emissions from New Passenger Cars" (COWI), Denmark, January 2002.

77 European Commission, above n 1, para 3.3.1.

78 Australia, Australian Government, above n 8. 
Clean Energy (Fuel Tax Legislation Amendment) Bill 2011 by reducing existing fuel tax credits by an amount equal to the carbon price, which was imposed through the existing fuel tax regime. Thus, it indirectly imposed an effective carbon price on business liquefied and gaseous fuel emissions. ${ }^{79}$

\section{$3 \quad$ Vehicle Taxes}

Potter et al. (2006) ${ }^{80}$ considered it important to target the taxation measure that has impact. The taxing point for the 'purchase of vehicles' and 'ownership of vehicles' are commonly referred to as 'vehicle taxes', which are generally designed for revenue generation rather than as an instrument to reduce carbon emissions. ${ }^{81} 82$ However, the base of such taxes can be carbon differentiated to provide a strong price signal to influence the acquisition of fuel-efficient and low $\mathrm{CO} 2$ emitting motor vehicles.

\subsection{Overview}

There is a growing body of literature that supports vehicle taxes as a means of providing strong price signals to influence consumers on the type of vehicles being purchased, by reducing $\mathrm{CO} 2$ emissions intensity in new passenger vehicles. ${ }^{83}$ Most vehicle taxes are paid annually and/or at the time of purchasing a new vehicle. For the purposes of this paper, the annual tax will be referred to as 'ownership tax'. This is commonly known as 'circulation tax' in the EU, and as 'registration tax' in Australia. The ownership tax is levied over the period the vehicles is owned and is normally recurrent in nature. ${ }^{84}$

79 Clean Energy (Fuel Tax Legislation Amendment) Bill 2011. The fuel tax credits will not be reduced for the agriculture, forestry and fishery industries. The Government had intended to introduce further legislation to apply a carbon price on heavy on-road vehicles from 1 July 2014, but this measure was not agreed to by all the members of the Multi-Party Climate Change Committee.

80 Stephen Potter et al., "Tax Treatment of employer commuting support" (2006) 26 Transport Reviews No. 221.

81 Australia, Australian Government, above n 8, 338.

82 Thomas Sterner, "Fuel taxes: an important instrument for climate policy" (2007) Energy Policy 1.

83 Growing literature supporting the reform of vehicle taxes differentiated on the basis of $\mathrm{CO} 2$ emissions, includes: European Commission, above n 1; Christian Brand, Jillian Anable and Martino Tran, above n 14.; Sean Giblin and Aonghus McNabola, 'Modelling the impacts of a carbon emission-differentiated vehicle tax system on $\mathrm{CO} 2$ emissions intensity from new vehicle purchases in Ireland' (2009) 37.4 Energy Policy 1404; Fionn Rogan et al, above n 2; Hugh Hennessy and Richard Toll, 'The impact of tax reform on new car purchases in Ireland' (2011) 39 Energy Policy 7059; France, International Energy Agency, Policy Pathways, Improving Fuel Economy of Road Vehicles $2012<\mathrm{http}$ //www.iea.org/publications/freepublications/ publication/Fuel_Economy_2012_WEB.pdf> at 14 October 2013, 32.

84 Uwe Kunert and Harmut Kuhfeld, "The diverse structures of passenger car taxation in Europe and the EU Commissions proposal for reform” (2007) 15 Transport Policy 306. 
A 'vehicle purchase tax' is paid at the time the new passenger vehicle is acquired, commonly known as a 'registration tax' in the EU, and 'stamp duty' in Australia. An alternative to a vehicle purchase tax is a 'feebate/bonus malus', which is a combination of a vehicle purchase tax/fee and a rebate/subsidy ${ }^{85}$ that rewards buyers of vehicles that are more fuel-efficient than the average vehicles, and penalizes buyers of less fuel efficient vehicles. ${ }^{86}$ In addition to vehicle taxes, most EU countries will also impose a 'Value Added Tax' (VAT), commonly known as a 'Goods and Services Tax' in Australia, based on the before-tax sale price of the new passenger car. Some EU countries differentiate the tax according to the vehicles' CO2 emissions. Further discussion of VAT is beyond the scope of this paper.

\subsection{EU studies support reforming vehicle taxes on basis of $\mathrm{CO} 2$ Emissions}

There have been several studies commissioned by the European Union on the transport CO2 emissions mitigation policies. Modeling prepared by COWI in 2002 (COWI study), a leading international consulting group, was commissioned by the European's Directorate-General for Environment (DG-ENV) in co-operation with the Directorate for Taxation and Customs Union (DG-TAXUD) ${ }^{87}$ to "study the potentials effects of fiscal framework measures to reduce $\mathrm{CO} 2$ emissions of new passenger cars". ${ }^{88}$ The object of the study was to determine which fiscal measures will assist the Commission to achieve the European Council and the European Parliaments target of reducing $\mathrm{CO} 2$ emissions from new passenger cars to $120 \mathrm{~g}$ of CO $2 / \mathrm{km}$ by 2005 , or by 2010 at the latest. ${ }^{89}$ The study considered the "CO2 efficiency of the national taxation system", and in light of the analysis, individual Member States were able to review their national taxation system. ${ }^{90}$

The COWI study found substantial variations in the vehicle taxation systems of nine selected Member States: Belgium, Denmark, Finland, Germany, Italy, Netherlands, Portugal, Sweden and the UK. The COWI Study selected these countries on the basis they were sufficiently representative of the following factors: GDP, population density, family structures, urbanization, taxation systems, income levels, income distribution, and whether there is a domestic production of cars or not. ${ }^{91}$

Of the selected countries, five countries do not have vehicle purchase taxes (Germany, Luxembourg, Sweden, France and the UK). However, France adopts a bonus-malus system, which grants a premium for the purchase of low emitting vehicles, explained

85 Kelly Gallagher and Erich Muehlegger, "Giving green to get green? Incentives and consumer adoption of hybrid vehicle technology" (2011) 61 Journal of Environmental Economics 1.

86 Christian Brand, Jillian Anable and Martino Tran, above n 14.

87 European Commission's Directorate-General for Environment, above n 76, 2.

88 Ibid.

89 Ibid 23.

90 Ibid 23.

91 Ibid 12 
in paragraph 5.1. The remaining four selected countries (Denmark, Finland, The Netherlands and Portugal) applied very high levels of vehicle purchase tax compared to ownership tax. There was no uniformity across the Member States on the design of the vehicle purchase taxes, which were typically based on the physical properties of the car such as cylinder capacity or fuel consumption, or related to the price of the car. ${ }^{92}$

The annual ownership taxes on passenger cars applied to all nine selected countries except France, which is a regional measure rather than a national one. ${ }^{93}$ Again, the average ownership taxes exhibited substantial variations among countries, and could be based on the vehicle's technical characteristics such as fuel type, dead weight, cylinder capacity, engine size, fuel consumption, and age of the vehicle. ${ }^{94}$

The findings from the COWI Study on the potential of reforming vehicle taxes as a measure to support the demand for more $\mathrm{CO} 2$ vehicles were as follows:

- Both vehicle purchase tax and ownership tax have the ability to provide CO2 reductions. No type of tax is superior to another; ${ }^{95}$

- It is essential to differentiate the taxes in such a way that taxes on very energy effective cars are significantly lower than taxes on cars with poor energy efficiency; ${ }^{96}$

- Enhancing the differentiation of existing systems can provide significant CO2 reductions. However, the modeling shows that the largest $\mathrm{CO} 2$ reductions occurred when existing tax systems were replaced by purely $\mathrm{CO} 2$ differentiated element for both vehicle purchase tax and ownership tax; ${ }^{97}$

- Simple increases of the taxes that do not involve changes to the tax base provide only very small $\mathrm{CO} 2$ reductions; ${ }^{98}$

- A shift to fuel efficient vehicles may increase the share of diesel vehicles that can provide further significant $\mathrm{CO} 2$ reductions. ${ }^{99}$

The COWI Study concluded that both vehicle taxes were effective measures in reducing $\mathrm{CO} 2$ emissions and supporting the target to reduce $\mathrm{CO} 2$ emissions from new cars down to a level of $120 \mathrm{~g} / \mathrm{km}$. Modeling from the COWI Study found that the average emissions of new passenger cars could be reduced on average by about 5 percent by 2008 if the existing tax base were converted to a CO2 differentiated system. 100

92 Ibid 42.

93 Ibid 13.

94 Ibid 42.

95 Ibid115.

96 Ibid 1.

97 Ibid 115.

98 Ibid 1.

99 Ibid 115.

100 Ibid. 
In terms of fuel taxes, the COWI Study found increasing fuel taxes by a further 25 percent would bring about only a very small reduction in the average $\mathrm{CO} 2$ emissions from new cars in the order of less than 1 percent. Only in a very few cases was the reduction more than 1 percent, but never above 2 percent. ${ }^{101}$ The COWI Study concluded that fuel taxes are not very effective as an instrument in reducing average $\mathrm{CO} 2$ emissions from new cars, but in a broader sense can encourage energy efficient driving behaviors. ${ }^{102}$ Further discussion of fuel taxes is outside the scope of this paper.

\subsection{EU vehicle taxes reformed to meet $\mathrm{CO} 2$ emission targets}

In 1998, the Association of European Car Manufacturers (ACEA) entered into a voluntary agreement with the European Commission under the Memorandum of Common Understanding 'to limit average emissions from newly registered passenger cars to $140 \mathrm{~g} / \mathrm{km}$ by $2008{ }^{1}{ }^{103}$ No fines were imposed if manufacturers failed to meet these standards.

In 2004, emissions from the average new car sold reached $163 \mathrm{~g} \mathrm{CO} 2 / \mathrm{km}$, which was 12.4 per cent below the 1995 starting point of $186 \mathrm{~g} \mathrm{CO} 2 / \mathrm{km} .{ }^{104}$ While efficiency improvements in car technology delivered most of the reductions in $\mathrm{CO} 2$ emissions, the rebound effect was that new cars sold in the EU during this period became significantly bigger and more powerful. ${ }^{105}$ By 2005 , it was clear that the ACEA would not meet the target of $140 \mathrm{~g}$ of CO2/km by 2008. ${ }^{106}$ On 5 July 2005, the European Commission (Commission) presented a proposal for a Directive that would require Member States to harmonize their vehicle taxes and link CO2 emissions to car taxes. ${ }^{107}$ At the time, only several Member States reformed their vehicle taxes to promote the acquisition of fuel-efficient vehicles. ${ }^{108}$

101 Ibid 21, 115.

102 Ibid 115.

103 European Commission, "Communication from the Commission to the Council and the European Parliament - Implementing the Community strategy to reduce $\mathrm{CO} 2$ emissions from cars: an environmental agreement with the European automobile industry", Brussels, 29 July 1998

104 European Commission, above n 1,8

105 Ibid.

106 Thomas Klier and Joshua Linn, "Using Vehicle Taxes to reduce carbon dioxide emission rates of new passenger vehicles: Evidence from France, Germany and Sweden" (2012) Resources for the Future <http://web.mit.edu/ceepr/www/publications/workingpapers/2012-011.pdf, $8>$ at 2 October 2013.

107 European Commission, "Passenger car related taxes directive" (Council Directive, Commission of European Communities) July $2005 \operatorname{COM}(2005) 261$.

108 European Commission, "Progress report on implementation of the Community's integrated approach to reduce $\mathrm{C} 02$ emissions from light duty vehicles" (Commission to the European Parliament, the Council and the European Economic and Social Committee) Brussels, November 2010. 
Again in 2007, the Commission reported to the Council and the European Parliament that notwithstanding that vehicle taxes "can significantly contribute to lowering the costs of compliance with efficiency targets", its implementation by Member States had been disappointing. ${ }^{109}$

The Commission proposed the adoption of concrete fiscal measures to "drive consumer demand towards fuel efficient cars: this would foster a more sustainable car market, where manufacturers can compete on grounds of environmental performance" without having to jeopardize improvements in comfort and safety considered to be important to consumers. ${ }^{110}$ Member States were reminded of their responsibility to reduce $\mathrm{CO} 2$ emissions through $\mathrm{CO} 2$ related taxes and other fiscal instruments. ${ }^{11}$

The Commission proposed a Council Directive to support the adoption of passenger car taxation, and to promote the "purchase of fuel efficient cars throughout the EU and help manufacturers in respect to the upcoming efficiency framework. ${ }^{112}$

To ensure regulatory targets be met, the European Parliament and the Council mandated the average new car fleet target by 2012, and set a long-term target of $95 \mathrm{gCO} 2 / \mathrm{km}$ by $2020 .{ }^{113}$ However, subsequent negotiations between the EU Member States and lobbying by the car industry persuaded the Commission to increase the original proposed target from a maximum of $120 \mathrm{~g}$ to $130 \mathrm{~g} \mathrm{CO} 2 / \mathrm{km}$, and delay the target date by a further three years from 2012 to 2015 with interim targets. ${ }^{114}$

Yet again, the Commission encouraged Member States to adopt differentiated "car taxation" based on carbon emissions as soon as possible, because it was a "powerful instrument" to influence the purchase decisions of the consumers by promoting the purchase of fuel efficient and low $\mathrm{CO} 2$ emitting cars. ${ }^{115}$

The car taxation measure would facilitate the efforts of the car manufacturers to meet their obligations to bring such fuel-efficient technology to the market, making it easier to meet their $\mathrm{CO} 2$ reduction target. ${ }^{116}$ Differentiated taxes would apply to all cars on the market. Car manufacturers also supported the introduction of tax measures to

109 European Commission, above n 1, 2.2.3.

110 Ibid 3.1

111 Ibid 3.3.

112 Ibid 3.3.1.

113 European Parliament and of the Council, "Setting emission performance standards for new passenger cars as part of the Community's integrated approach to reduce $\mathrm{CO} 2$ emissions from light-duty vehicles: Regulation (EC) 443/2009" <http://eur-lex.europa.eu/LexUriServ/ LexUriServ.do?uri=OJ:L:2009:140:0063:008:en:PDF accessed on 14 October 2013> at 14 October 2013.

114 Greenpeace, "Claims versus reality: How the European car lobby proved itself wrong", Climate Consultations, 2 December $2011<$ http://ec.europa.eu/clima/consultations/0012/citizens/ barry_dagleish_claims_v_reality_en.pdf> at 19 April 2013.

115 European Commission, above n 1, 3.3.1.

116 Ibid. 
shape consumers' demand towards fuel-efficient cars, and help create a market for breakthrough technologies. ${ }^{117}$

By 2008, many Member States commenced reforming the base of their vehicle's taxation systems to $\mathrm{CO} 2$ differentiation emission rates. ${ }^{118}$ The reform measures entailed either a complete redesign of the vehicle taxation system or additional CO2 emission taxes or subsidies being added to the pre-existing taxes. ${ }^{119}$

\subsection{Vehicle taxes vary between Member States in the EU}

By 2012, 19 of the 27 European Union (EU) Member State countries imposed some form of $\mathrm{CO} 2$ based vehicle taxes to the vehicle purchase tax and/or ownership tax of passenger cars, compared with 11 in 2007 and nine in 2006. ${ }^{120}$ Eight of the 19 countries applied some form of CO2 tax on both vehicle taxes (Denmark, Cyprus, Finland, France, Ireland, Malta, Portugal and The Netherlands); six countries applied some form of $\mathrm{CO} 2$ tax only on the vehicle purchase tax (Austria, Belgium, Latvia, Romania, Slovenia and Spain); and five countries applied some form of $\mathrm{CO} 2$ tax only on the ownership tax (Germany, Greece, Sweden, Luxembourg and the UK). ${ }^{121}$

Any inter-country comparisons should be "done with utmost care" as the total achievable reduction in $\mathrm{CO} 2$ emissions can vary depending on the degree of tax differentiation adopted by the country; further, the implemented system can be complex and quite different from country to country. ${ }^{122}$ Table 3 shows the performance

117 ACEA, "Vehicles In Use: The Automobile Industry Pocket Guide" (2012) European Automobile

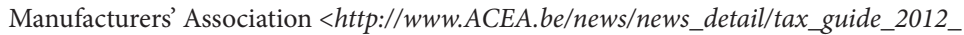
incentives_increase_further/> at 2 April 2013.

118 Lisa Ryan, Susana Ferreira and Frank Convery, "The impact of fiscal and other measures on new passenger car sales and CO2 emissions intensity: Evidence from Europe” (2009) 31 Energy Economics 365; Fionn Rogan et al, above n 2; Thomas Klier and Joshua Linn, above n 116. Thomas Klier and Joshua Linn, above n 116 examined the fiscal measures such as vehicle taxes to influence consumers to choose mover fuel-efficient vehicles.

119 Thomas Klier and Joshua Linn, above n 106.

120 ACEA, "Overview of CO2-Based Motor Vehicle Taxes in the EU" (2013) European Automobile

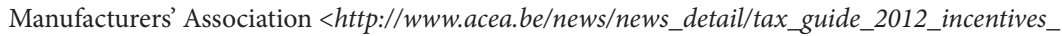
increase_further/> at 15 October 2013.

121 Ibid.

122 Uwe Kunert and Harmut Kuhfeld, above n 84 refers to the vehicle tax systems in Europe, being very diverse. This applies to the types of charges, the multitude of assessment bases and the tax scales: Zahedi and L Cremades, Taxes in "EU Countries: How Fair is their Calculation? (2012) XVI International Congress of Engineering Projects", (University of Politecnica de Catalunya, Barcelona) <http://upcommons.upc.edu/e-prints/bitstream/2117/18150/1/vehicles. pdf $>$ refers to the fact that vehicle taxes in the EU are very complex and vary from country to country, and not all vehicle taxes are efficient for the purposes of reducing $\mathrm{CO} 2$ emissions.: European Commission, European Commission's Directorate-General for Environment, above $\mathrm{n}$ 76., refers to the types of taxes that are in effect in the Member States. The specific design of the taxes differ substantially between the Member States, in terms of the level of taxation; the extent to which differentiation is applied and the tax base in use 
of nine EU members' states in reducing CO2 emissions by reforming existing vehicle taxes and applying some form of $\mathrm{CO} 2$ tax to the ownership and/or vehicle purchase taxes.

Table 3: New car purchase tax and average $\mathrm{CO} 2$ emissions from new passenger cars by Member State

\begin{tabular}{|c|c|c|c|c|c|c|}
\hline Countries & $\begin{array}{l}2008 \\
\mathrm{CO} 2 \mathrm{~g} / \\
\mathrm{Km}^{*}\end{array}$ & $\begin{array}{l}2009 \\
\mathrm{CO} 2 \mathrm{~g} / \\
\mathrm{Km} *\end{array}$ & $\begin{array}{l}2010 \\
\mathrm{CO} 2 \mathrm{~g} / \\
\mathrm{Km}^{*}\end{array}$ & $\begin{array}{l}2011 \\
\mathrm{Co2g} / \\
\mathrm{Km}^{\star *}\end{array}$ & $\begin{array}{l}2012 \\
\mathrm{Co2g} / \\
\mathrm{Km}^{\star \star}\end{array}$ & $\begin{array}{l}\% \\
\text { Change } \\
2007- \\
2012^{\star *}\end{array}$ \\
\hline \multicolumn{7}{|l|}{ Ownership taxes } \\
\hline Germany & 164.8 & 154 & 151.2 & 145.6 & 141 & -17.0 \\
\hline United Kingdom & 158.2 & 149.7 & 144.2 & 138.1 & 133 & -18.8 \\
\hline \multicolumn{7}{|l|}{$\begin{array}{l}\text { Vehicle purchase } \\
\text { taxes }\end{array}$} \\
\hline Belgium & 147.8 & 142.1 & 133.4 & 130.0 & 128 & -16.4 \\
\hline Spain & 148.2 & 142.2 & 138.0 & 136.0 & 132 & -16.0 \\
\hline \multicolumn{7}{|l|}{ Bonus malus } \\
\hline France & 140.1 & 133.5 & 130.5 & 127.7 & 124 & -16.8 \\
\hline \multicolumn{7}{|l|}{$\begin{array}{l}\text { Vehicle purchase } \\
\text { tax and ownership } \\
\text { taxes }\end{array}$} \\
\hline Ireland & 156.8 & 145 & 133.2 & 128.2 & 125 & -24.2 \\
\hline Portugal & 138.2 & 133.8 & 127.3 & 122.8 & 119 & -16.6 \\
\hline Denmark & 146.4 & 139.1 & 126.6 & 125.0 & 117 & -25.7 \\
\hline Netherlands & 156.7 & 146.9 & 135.8 & 126.2 & 123 & -25.1 \\
\hline
\end{tabular}

* Source: European Environment Agency

** Source: ACEA Pocket Guide 2013 http://www.acea.be/uploads/publications/CO2_tax overview_2013.pdf

Countries with the most effective $\mathrm{CO} 2$ tax schemes had the biggest reductions in carbon emissions and the lowest average $\mathrm{CO} 2$ emissions from new passenger cars, as shown in Table 3.

\subsection{Member States that adopt both vehicle taxes}

Table 3 shows that The Netherlands, Denmark, Portugal and Ireland have imposed both vehicle taxes (acquisition and ownership), and have the lowest average CO2 
specific emissions from newly registered vehicles in Europe, below the average emissions $\mathrm{CO} 2$ target of $130 \mathrm{gCO} 2 / \mathrm{km} .{ }^{123}$

Denmark has the highest vehicle purchase tax followed by The Netherlands, which is reflected in both countries having the lowest average emissions for new cars of any Member States. ${ }^{124}$ The Netherlands made significant progress in 2011 by jumping from seventh place in 2010 to second in 2011, largely due to tax changes encouraging sales of lower $\mathrm{CO} 2$ vehicles. ${ }^{125}$

Ireland has the fourth highest tax burden on petrol and diesel car ownership within the EU 25. ${ }^{126}$ Rogan (2011) $)^{127}$ found that the policy change in vehicle taxes acted as a strong price signal and consumer's response was greater than expected, evidenced by the reduction in Ireland's average emissions from new passenger vehicles by 29.3 percent within four years of introducing vehicle purchase taxes in 2008. In effect, Ireland's vehicle taxation system has reduced the country's average carbon emissions for new vehicles within a comparatively short time frame.

\section{Case study: Ireland}

Ireland is chosen as a case study because of the country's similarities with Australia. Namely, Ireland had to address the significant growth ${ }^{128}$ in the transport sector and the growing preference for high emitting vehicles. ${ }^{129}$

123 European Union, European Environment Agency, "Monitoring CO2 emissions from new passenger cars in the EU: summary of the data for 2012" www.eea.europa.eu/publications/ monitoring CO2 emissions from new passenger cars in the EU-2.pdf $>$ at 22 April 2013.

124 Amela Ajanovic and Haas Reinhard, "The role of efficiency improvements vs. price effects for modeling passenger car transport energy and demand- Lessons from European countries" (2012) 41 Energy Policy 36.

125 Anon, "Europe cleaning up act as car CO2 targets loom" (2012) JATO <http://www.jato.com/ PressReleases/Europe\%20cleaning\%20up\%20act\%20as\%20car\%20CO2\%20targets\%20loom. pdf> AT 5 July 2013.

126 Uwe Kunert and Harmut Kuhfeld, above n 84.

127 Fionn Rogan et al, above n 2.

128 Brian O'Gallachoir, Martin Howley and Morgan Bazilian, "How private car purchasing trends offset efficiency gains and the successful energy policy response" (2009) 37 Energy Policy 3790. The growth of transport emissions outstripped the growth in other sectors. The emissions growth varied across the years: $11.4 \%$ per annum growth in the period 1995-2000, compared with annual growth of 3.3 per cent between 1990 to 1995. In 2006, the transport sector was the only sector exhibiting significant growth in the energy-related $\mathrm{CO} 2$ emissions. If there had been no growth in the transport sector, there would have been an overall redcution in emissions of 2.8 percent in overall energy related CO2 emissions. 3791

129 European Commission, "Communications from the Commission to the European Parliament, the Council and the European Economic and Social Committee," (COM) Brussels, February 2007. 


\subsection{Growth of Ireland's transport emissions}

The transport sector accounted for 19.9 percent of CO2 emissions in 1990 and increased to 34.6 percent by 2006 due to an annual growth rate of 6.5 per cent. ${ }^{130}$ Given this, the National Climate Change Strategy in Ireland ${ }^{131}$ forecasted that this sector would account for the largest increase in emissions by 2010 if no policy measures were taken.

Additionally, the European Union assigned specific emission reduction targets for each Member State in order to support reaching its target of 20 percent GHG reduction relative to 1990 levels by $2020 .{ }^{132}$ Ireland's assigned reduction target in non-ETS emissions was 20 percent compared to 2005 levels by 2020 . This target would require a reduction of 1.29 percent annually between 2009 and $2020 .{ }^{133}$

Ireland focused its reforms on private car transport because in 2007 it accounted for 37.5 percent of transport GHG emissions and 12 percent of non-ETS GHG emissions. ${ }^{134}$ Transport CO2 emissions rose sharply between 1990 and 2007 when the stock of cars on Irish roads more than doubled. ${ }^{135}$ Between 1990 and 2007 there was a 182 percent (6.3 percent per annum) growth in energy-related $\mathrm{CO} 2$ emissions from the transport sector, ${ }^{136}$ thus making it extremely challenging for Ireland to achieve the projected 1.29 percent annual reduction in non-ETS emissions.

At the time, smaller cars in the $900 \mathrm{cc}$ were declining in numbers, compared to strong growth in the $1.7-1.91 \mathrm{cc}$, and greater than $1.91 \mathrm{cc}$ range, indicating a growing trend toward purchasing larger vehicles. ${ }^{137}$ Thus, cars with engines greater than $1.71 \mathrm{cc}$ increased their share from 13 percent in 1990 to 29 percent in 2006, with the market in this period being dominated by petrol cars. ${ }^{138}$

The challenge in Ireland (as it remains in Australia) was to address consumers' growing preference to buy larger vehicles. The choice of vehicle by consumers can have a significant impact on $\mathrm{CO} 2$ emissions. For example, an SUV on average has 70 percent more emissions than a smaller $\operatorname{car}^{139}$ as discussed in paragraph 2.3.

130 Brian O'Gallachoir, Martin Howley and Morgan Bazilian, above n 128: 3791.

131 Ireland, Irish Governement: The Department of Environment and Urban Economics, "National Climate Change Strategy in Ireland" (NCCSI), Dublin, 2007.

132 Hannah Daly and Brian O'Gallachoir, "Modelling private car energy demand using a technological car stock model” (2011) 99(4) Transportation Research Part D: Transport and Environment 1145.

133 Ibid.

134 Ibid.

135 Ireland: Martin Howley, Fergal O’Leary and O’Gallachoir “Sustainable Energy Ireland”, Energy in Transport 2007 Cork, October 2007.

136 Ibid.

137 Brian O'Gallachoir, Martin Howley and Morgan Bazilian, above n 128.

138 Ibid.

139 Great Britain, British Government, "King Review of low-carbon cars"(Professor Julia King) Birmingham, March 2007. 
Petrol/electric hybrids can have $\mathrm{CO} 2$ emissions up to 30 percent below their petrol or diesel equivalents with the Toyota Yaris hybrid emitting just $79 \mathrm{~g} / \mathrm{km}$ compared with $104 \mathrm{~g} / \mathrm{km}$ for the lowest diesel Yaris in 2012. ${ }^{140}$ Therefore, choosing a more fuel-efficient vehicle achieves financial savings, as the vehicle requires less fuel for the same distance travelled and produces less $\mathrm{CO} 2$ emissions as a result of lower fuel use. ${ }^{141}$

\subsection{Ireland's vehicle tax base shifts from engine size to $\mathrm{CO} 2$ emissions}

Ireland reformed its vehicle taxes on 1 July 2008, and targeted the car purchasing trends by changing the basis of vehicle taxation from engine size to (potential) emissions per kilometer on both the vehicle purchase tax and ownership tax. This was done in order to ensure that any private car manufacturers efficiency gains were not offset by purchasing trends. ${ }^{142}$ The change affects new private cars but has no effect on usage costs, ${ }^{143}$ with older cars remaining on the prior 'engine size' based systems. ${ }^{144}$

The reforms introduced to Irelands vehicle taxes were as follows:

Table 4: Reform of Irelands vehicle taxes introduced 1 July 2008

\begin{tabular}{l|l|l|l|l}
$\begin{array}{l}\text { CO2 } \\
\text { emission } \\
\text { bands }\end{array}$ & $\mathbf{C O 2 g}$ //km & $\begin{array}{l}\text { Annual } \\
\text { ownership } \\
\text { tax } \\
\text { (EUR) }\end{array}$ & $\begin{array}{l}\text { *Vehicle } \\
\text { purchase tax } \\
(\%) \text { per vehicle }\end{array}$ & $\begin{array}{l}\text { Example } \\
\text { Vehicle cost 50,000 } \\
\text { EUR }\end{array}$ \\
\hline A & $0-120 \mathrm{~g}$ & 104 & 14 & 7,000 \\
\hline $\mathrm{B}$ & $121-140 \mathrm{~g}$ & 156 & 16 & 8,000 \\
\hline $\mathrm{C}$ & $141-155 \mathrm{~g}$ & 302 & 20 & 10,000 \\
\hline $\mathrm{D}$ & $156-170 \mathrm{~g}$ & 447 & 24 & 12,000 \\
\hline $\mathrm{E}$ & $171-190 \mathrm{~g}$ & 630 & 28 & 14,000 \\
\hline $\mathrm{F}$ & $191-225 \mathrm{~g}$ & 1,050 & 32 & 16,000 \\
\hline $\mathrm{G}$ & $226 \mathrm{~g}+$ & 2,100 & 36 & 18,000 \\
\hline
\end{tabular}

Source: Rogan et al., 2011:585

*Vehicle purchase tax calculated on "open market selling price", which is the expected retail price including all taxes, (including VAT).

140 United Kingdom, The Society of Motor Manufacturers and Traders (SMMT), "Driving the Motor Industry New Car CO2 Report 2013, The 23rd Report" < http://www.lowcvp.org.uk/ assets/reports/SMMT-New-Car-CO2-Report-2013-web.pdf> at 15 July 2013.

141 British Government, above n 139.

142 Fionn Rogan et al., above n 2.

143 Hugh Hennessy and Richard Toll, above n 83, 7060.

144 Miao Fu and Andrew Kelly, "Carbon related taxation policies for road transport: Efficacy of ownership and usage taxes, and the role of public transport and motorist cost of perception on policy outcomes" (2012) 22 Transport Policy 57. 
The tax rates linked to specific bands of $\mathrm{CO} 2$ emissions $(\mathrm{g} / \mathrm{km})$ as shown in Table 4 are significantly differentiated for the purpose of influencing the purchase decision of consumers to choose less $\mathrm{CO} 2$ emitting vehicles. ${ }^{145}$ Charging an 'up-front' vehicle purchase tax in addition to the vehicle price has elevated the environment and the vehicles $\mathrm{CO} 2$ emissions from 'least important' to an 'important factor' for consumers when deciding which car to buy.

Table 5: Comparison of ownership taxes in Ireland and the UK

\begin{tabular}{l|l|l|l}
\hline \multirow{2}{*}{ Emissions } & \multicolumn{2}{|c|}{ UK rates } & Irish rates \\
& GBP & EUR & EUR \\
\hline Up to 100 & 0 & 0 & 104 \\
\hline 101 to 110 & 35 & 40 & 104 \\
\hline $111-120$ & 35 & 40 & 104 \\
\hline $121-120$ & 120 & 140 & 156 \\
\hline $131-140$ & 120 & 140 & 156 \\
\hline $141-150$ & 125 & 145 & 302 \\
\hline $151-165$ & 150 & 175 & 447 \\
\hline $166-175$ & 175 & 204 & 447 \\
\hline $176-185$ & 175 & 204 & 630 \\
\hline $186-200$ & 215 & 251 & 630 \\
\hline $201-225$ & 215 & 251 & 1050 \\
\hline $226-255$ & 405 & 472 & 2100 \\
\hline Over 255 & 405 & 472 & 2100 \\
\hline
\end{tabular}

Source: Hennessey et al., 2011

Table 5 shows that Ireland's annual ownership taxes rates are significantly differentiated according to the vehicles $\mathrm{CO} 2$ emissions, and this is evidenced when comparing Ireland's tax rates with those of the UK.

For example, if a consumer prefers to buy a new car on the basis of power and engine size but finds the vehicle emits $226 \mathrm{~g}$ of CO $2 / \mathrm{km}$, then the tradeoff for the consumer's preference is an additional 'up front' vehicle purchase tax in Band G of EUR 18,000 (Table 4) and higher annual ownership taxes of EUR 2,100 (Table 5).

In effect, Ireland's high carbon differentiated vehicle taxes has provided a strong price signal and successfully influenced consumers to buy lower carbon-emitting vehicles. Namely, before the new taxes were introduced, the share of lower emitting vehicles of less than $155 \mathrm{~g} / \mathrm{km}$ in bands A-C was on average $41 \%$ in $2006 / 2007$. After the new taxes were announced, in the period July 2008 - December 2008, the share of these three bands rose to 73 percent, and increased again to 78 percent in 2010 , and to 91 percent in 2011. ${ }^{146}$ The largest increase in sales after the tax change was in B label band $(120-140 \mathrm{~g} / \mathrm{km})$ rising from 23 percent to 41 percent. ${ }^{147}$

145 Fionn Rogan et al., above n 2.

146 Fionn Rogan et al., above n 2, 588.

147 Ibid. 
The largest reduction was in the sales of high emitting new private vehicles was in the following emission bands: ${ }^{148}$

Band D (>155-170g) 24 percent in 2007 to 6 percent in 2010

Band E to F (>170-225) 34 percent in 2007 to 3 percent in 2010

\subsection{Ireland's significant reduction in average $\mathrm{CO} 2$ emissions from new cars}

Rogan et al. (2011) ${ }^{149}$ found the fiscal measure had a much larger than expected impact on reducing $\mathrm{CO} 2$ emissions. That is, before introducing the vehicle taxation reforms, the average CO2 emissions between 2000 and 2007 were around $166 \mathrm{~g} / \mathrm{km}$ for both new petrol and diesel cars, which reduced by 13 percent to $145 \mathrm{~g} / \mathrm{km}$ in the first year (2009), saving 5.9 ktCO2 because of a significant shift to diesel cars. ${ }^{150}$ Further reductions in GHG of 16.8 per cent from 2009 to 2011 as shown in Table 3, placed the average CO2 emissions of new car fleet at $128.3 \mathrm{~g} / \mathrm{km}$, meeting the 2015 EU target of $130 \mathrm{~g} / \mathrm{km}$ by 2012 . Overall, Ireland recorded the highest total reduction in weighted average CO2 emissions of 22.7 per cent in the period 2007 to 2011, as shown in Table 3. That is, the magnitude of change in the weighted average $\mathrm{CO} 2$ emissions is shown when compared with EU data. Within one year of introducing the new emission based taxation system for new private cars, Ireland's vehicle emissions went from 8 percent above the EU average of $154 \mathrm{~g} / \mathrm{km}^{151}$ to 6 percent below. ${ }^{152}$

Such an immediate and significant change in purchasing patterns towards loweremitting vehicles resulting from the significant $\mathrm{CO} 2$ tax differentiation strongly supports the effectiveness and impact of this environmental tax instrument in reducing CO2 emissions. Rogan $(2011)^{153}$ also asserted that the decline in new private car sales in 2008 to close to 2003 levels and a further 62 percent decline in 2009 were a result of the economic recession in Ireland, rather than the impact of the change in vehicle taxes. ${ }^{154}$ The decline in Irish new car sales was comparable to those in the EU. ${ }^{155}$

\section{$5 \quad$ Alternative mechanisms to vehicle purchase tax}

The following mechanisms are alternatives to the vehicle purchase tax, such as the bonus malus scheme, or those imposed in addition to the vehicle purchase tax, such as

\footnotetext{
148 Ibid.

149 Ibid.

150 Ibid.

151 ACEA, "Industry Report" (2009) European Automobile Manufacturers' Association sighted at $<$ www.acea.be/statistics> at 2 April 2013.

152 Fionn Rogan et al., above n 2.

153 Ibid.

154 Ibid 589.

155 Ibid.
} 
the annual CO2-based ownership tax, or special tax incentives provided to encourage the uptake of alternative fuelled vehicles, such as electric vehicles.

\subsection{Bonus malus scheme}

Some commentators have suggested that the French bonus/malus scheme may be more publically acceptable than other fiscal measures because of the reward element. ${ }^{156}$ Brand et al. $(2013)^{157}$ found more ambitious feebate schemes were faster in accelerating low carbon and plugged-in technology uptake, particularly in the short to medium term.

France reformed its vehicle purchase tax in January 2008, and began taxing and subsidizing purchase according to the vehicle's emissions rate. ${ }^{158}$ Under a bonus malus, a premium is granted for the purchase of a new car when its $\mathrm{CO} 2$ emissions are $105 \mathrm{~g} / \mathrm{km}$ or less. ${ }^{159}$ Vehicles emitting $20 \mathrm{~g} / \mathrm{km}$ or less of $\mathrm{CO} 2$ benefit from a maximum premium of EUR 7,000, but the incentive cannot exceed 20 percent of the vehicle purchase price, including VAT. ${ }^{160}$ The premium reduces to EUR 5,000 for vehicles emitting between $20 \mathrm{~g} / \mathrm{km}$ and $50 \mathrm{~g} / \mathrm{km}$, and EUR 4,500 when CO2 emissions are between $50 \mathrm{~g} / \mathrm{km}$ and $60 \mathrm{~g} / \mathrm{km} .{ }^{161}$

An additional bonus of EUR 200 applies when a car at least 15 years old is scrapped and the new car purchased emits a maximum of $105 \mathrm{~g} / \mathrm{km},{ }^{162}$ while hybrid vehicles emitting $110 \mathrm{~g} / \mathrm{km}$ or less benefit from a premium of EUR 2,000. Electric vehicles are exempt from company tax, and hybrid vehicles emitting less than $110 \mathrm{~g} / \mathrm{km}$ are exempt during the first two years after registration. ${ }^{163}$

A malus is payable when the $\mathrm{CO} 2$ emissions from the new car purchased exceeds $135 \mathrm{~g} / \mathrm{km}$. The maximum malus paid is EUR 6,000 when $\mathrm{CO} 2$ emissions exceed $200 \mathrm{~g} / \mathrm{km}$. In addition to this one-off malus paid at the time of purchase, cars emitting more than $190 \mathrm{~g} / \mathrm{km}$ pay a yearly tax of EUR $160 .{ }^{164}$ This is in addition to the annual ownership tax.

The French reacted more favourably to the scheme than expected, accounting for a EUR 500 million loss in 2010, and this prompted a readjustment to the vehicle purchase taxes and subsidies. ${ }^{165}$ Thus, a feebate program must be carefully designed,

156 Sashank Musti and Kara Kockleman, "Eovlution of the household vehicle fleet: Anticipating fleet composition, PHEV adoption and GHG emissions in Austin, Texas" (2011) 45

Transportation Research: Policy and Practice 707.

157 Christian Brand, Jillian Anable and Martino Tran, above n 14.

158 Thomas Klier and Joshua Linn, above n 106, 31.

159 ACEA, above n 117.

160 Ibid.

161 Ibid.

162 Ibid.

163 Ibid.

164 Ibid.

165 Christian Brand, Jillian Anable and Martino Tran, above n 14, 135. 
monitored, and adjusted to counter the problems of costs, demand effects, and tax revenues. ${ }^{166}$

\subsection{Annual CO2-based ownership tax}

Table 3 shows that Germany imposed only an annual CO2 based ownership tax, and had the highest average $\mathrm{CO} 2$ emission for new passenger vehicles of $141 \mathrm{~g}$ of CO2 per kilometer, exceeding the EU average of $136 \mathrm{~g} / \mathrm{km}$ for $2012 .^{167}$. That is, in 2009 Germany changed its ownership taxes based on engine size to a tax based system that accounted for a vehicle's CO2 emission rate. ${ }^{168}$ However, the rate of tax is so low (EUR 50/ EUR 70 per car) that its impact on car choice is negligible. ${ }^{169}$ The OECD found that Germany's measures were not providing a clear carbon price signal. ${ }^{170}$ Consequently, the average $\mathrm{CO} 2$ emissions from new cars in Germany are one of the worst performing of all Member States. ${ }^{171}$ Klier and Linn (2012) ${ }^{172}$ observed that a possible explanation for this is that consumers are more responsive to the vehicle purchase tax than to annual ownership taxes, because of the uncertainty over future ownership taxes.

\subsection{Special tax incentives for low $\mathrm{CO} 2$ emission vehicles}

To promote the lowest carbon emission vehicles such as electric, hybrid, and other alternative fuel vehicles, vehicles taxes are exempt for several EU Member States. For example, Denmark exempts electric vehicles weighing less than 2,000 kg from its vehicle taxes. However, this exemption does not apply to hybrid vehicles. Similarly in Germany, electric vehicles are exempt from annual ownership taxes for a period of five years. ${ }^{173}$

In Ireland, electric vehicles are exempt from vehicle purchase tax up to a maximum of EUR 5,000. Plug-in hybrids benefit from a vehicle purchase tax of EUR 2,500, and conventional hybrid vehicles and other flexible fuel vehicles benefit from a vehicle purchase tax to a maximum of EUR 1,500. ${ }^{174}$

166 Ibid.

167 National Transport Commission, above 57: 24

168 Thomas Klier and Joshua Linn, above n 106

169 Stephen Potter et al., n 71, 222.

170 OECD, "Economic Surveys: Germany" 2012, 81-116: Germany is the largest national emitter in the European Union and the third largest in the OECD after the United States and Japan. The motor vehicle tax on ownership was reformed in 2009 to include CO2 components in the tax base. However, these measures are not providing a clear carbon price signal: 92 . The OECD in its Economic Survey of Germany, recommended the adoption of "motor vehicle tax to encourage the adoption of energy efficient cars." 93.

171 ACEA, above n 117;

172 Thomas Klier and Joshua Linn, above n 106, 2.

173 ACEA, above n 117.

174 Ibid. 
In the Netherlands, electric vehicles are exempt from registration tax and annual circulation tax, and hybrids are exempt if they emit less than $95 \mathrm{~g} / \mathrm{km}$ (diesel) or less than $110 \mathrm{~g} / \mathrm{km}$ (petrol). ${ }^{175}$

Special tax incentives are provided under the bonus malus system discussed in paragraph 5.1.

\section{Ex post evidence on success of carbon differentiated vehicle taxes}

Literature on the effectiveness of "carbon differentiated vehicle tax' measures has been mixed. ${ }^{176}$ Many of the earlier studies prior to 2007 outlined possible policy responses to reforming vehicle taxes, based on the engine size to $\mathrm{CO} 2$ emissions. The response depended on the whether the price signal of the possible policy design was significant to influence a behavioural shift to lower $\mathrm{CO} 2$ emitting vehicles.

Rogan et al (2011) found that only a few studies have specifically been ex post of the policy change, but none have assessed the impact of the reform of the car taxation policy aimed at reducing emissions. ${ }^{177}$ That is, Rogan et al (2011) provided an ex post analysis of the first full year of the policy change in vehicle taxes, introduced in Ireland in July 2008, by analyzing the purchasing trends in terms of specific CO2 emissions, engine size and fuel, implications on car prices, level of $\mathrm{CO} 2$ abatement, new car $\mathrm{CO} 2$ intensity, and revenue gathered. ${ }^{178}$ Hennessy et al.'s (2011) ex post analysis of the 2008 vehicle tax reform in Ireland found that the impact on new passenger car sales was far larger than the schemes analyzed in the previous studies. ${ }^{179}$

Furthermore, there is a conflict in the literature as to which vehicle tax is effective in influencing the demand for low CO2 emitting vehicles. The COWI Study (2002) discussed in paragraph 3.2 found that both vehicle purchase tax and ownership taxes have the ability to provide $\mathrm{CO} 2$ reduction, and that no type of tax was superior to another.

Earlier literature by Ryan et al. (2009) ${ }^{180}$ performed an econometric modeling study using data from 1995 to 2004, and suggested that the vehicle purchase tax did not appear to have an important impact to the $\mathrm{CO} 2$ emissions intensity of the new passenger car fleet over and above the effects of ownership and fuel taxes. ${ }^{181}$ The study concluded that, "it is the ownership tax (or circulation tax) that is more influential in determining fuel efficiency and hence $\mathrm{CO} 2$ emissions of the vehicle

175 ACEA, above $\mathrm{n} 117$.

176 Christian Brand, Jillian Anable and Martino Tran, above n 14, 136.

177 Fionn Rogan et al, above n 4, 584

178 Ibid.

179 Hugh Hennessy and Richard Toll, above n 83, 7064

180 Lisa Ryan, Susana Ferreira and Frank Convery, above n 118.

181 Lisa Ryan, Susana Ferreira and Frank Convery, above 118: 373 
purchased." 182 However, Ryan et al. (2009) stated that vehicle purchase taxes 'may have the potential to affect consumer behavior directly as they are applied at the point of sale and influence whether a customer purchases a diesel or petrol vehicle.' ${ }^{183}$

Brand et al.s (2013) ${ }^{184}$ study differed from Ryan et al's (2009), ${ }^{185}$ because the vehicle purchase taxes investigated between 1995 and 2004 by the latter were different in design and ambition than the ones modelled by the former. Any differences between the studies were because of different settings such as socio-economic, political, prevailing pricing and taxation, vehicle fleet characteristics, policy setups, and analytical methods used. ${ }^{186}$

For example, when compared to the UK ownership tax policy design, the Irish $\mathrm{CO} 2$ emission bands have a wider range and, given that the UK has no vehicle purchase tax, explains why the Irish carbon- differentiated tax scheme has a larger effect.

Further, Mayeres and Proost (2001), ${ }^{187}$ and Giblin and McNabola (2009) ${ }^{188}$ found annual ownership taxes have a larger impact on individual choices than vehicle purchase taxes. Giblin and McNabola (2009) ${ }^{189}$ observed that as the quoted purchase price of the new passenger vehicle is inclusive of the vehicle purchase tax, the purchaser might not view this as an extra carbon-related cost. Moreover, any extra annual ownership tax will depend on the carbon intensity of the vehicle chosen by the consumer. ${ }^{190}$ The findings by Beck et al. (2011) ${ }^{191}$ have suggested that annual and variable emissions charges can be viewed as contributing drivers for individuals to be willing adopters of hybrid technology. This can result in significant behavioral change in line with reducing vehicle $\mathrm{CO} 2$ emissions.

Modeling by Klier and Linn (2012) ${ }^{192}$ found that consumers respond more to purchase taxes than to annual ownership taxes, and that a possible explanation for this is that consumer preferences simply differ across countries. ${ }^{193}$ Meghan et al.

\footnotetext{
182 ibid

183 ibid

184 Christian Brand, Jillian Anable and Martino Tran, above n 14, 144

185 Lisa Ryan, Susana Ferreira and Frank Convery, above n 118.

186 Christian Brand, Jillian Anable and Martino Tran, above n 14, 144.

187 Inge Mayeres and Stef Proost, "Should diesel cars in Europe be discouraged?" (2000) 31(4) Regional Science and Economics 453.

188 Sean Giblin and Aonghus McNabola, n 78, 1410.

189 Ibid.

190 Ibid.

191 Matthew Beck, John Rose and David Hensher, "Behavioural responses to vehicle emissions charging" (2011) 38 Transportation No. 3 445, 461.

192 Thomas Klier and Joshua Linn, above n 106, 22.

193 Ibid 22.
} 
(2006), ${ }^{194}$ Chetty (2009), ${ }^{195}$ and Finkelstein (2009) ${ }^{196}$ found consumers are more responsive to tax and price changes that are more prominent.

The ex-post analysis by Rogan et al. (2011) ${ }^{197}$ agreed with the COWI (2002) study discussed in paragraph 3.2, and found both vehicle taxes in Ireland provided a very definite and strong pricing signal towards low emitting vehicles. Mandell (2009)198 found that changes to the vehicle taxes could affect the purchase and ownership of new passenger vehicles. The advantage of imposing both taxes is that a $\mathrm{CO} 2$ differentiated vehicle purchase tax will provide an incentive for buyers to choose a vehicle with lower emissions, and a recurrent ownership tax will give buyers of used cars an incentive to switch to vehicles with lower emissions; however, this is not the case with one-off taxes. ${ }^{199}$

The findings of Brand et al's (2013) ${ }^{200}$ study are generally in line with other studies, with the car purchase feebate policies shown to be the most successful and effective policy instrument in accelerating low carbon technology uptake and reducing GHG emissions. Moreover, "if designed carefully and adjusted over time, [it] can avoid overburdening consumers with ever more taxation whilst ensuring revenue neutrality" ${ }^{201}$

The effectiveness of the various vehicle taxation schemes shown in Table 3 shows that policy choice, design, and rate differentials play a crucial role in determining the strength of the behavioural response in transitioning to low emission transport and achieving the national policy goal or targets of reducing road transport emissions.

Therefore, Rogan et al. (2011) stated that the early signs of vehicles taxes differentiated on the basis of the vehicles $\mathrm{CO} 2$ emissions are particularly effective:

"This should help raise the profile of this type of policy, particularly when studies that seek to find policy solutions to the transport energy challenge, fail to include a car tax policy that drives lower emissions." 202

194 Meghan Busse, Jorge Silva-Russo and Florian Zettlemeyer, "\$1000 Cash-Back: The PassThrough of Auto Manufacturing Promotions" (2006) 96(4) American Economic Review 1253.

195 Raj Chetty, Adam Looney and Kory Kroft, "Salience and Taxation: Theory and Evidence" (2009) 99(4) American Economic Review 1145.

196 Amy Finkelstein, “E-Z Tax: Tax Salience and Tax Rates" (2009) 124(3) Quarterly Journal Economics 969.

197 Fionn Rogan et al, above n 2.

198 Svante Mandell, "Policies Towards a More Efficient Car Fleet" (2009) 37(12) Energy Policy 5184.

199 Denmark, OECD and European Environment Agency, "Comparisons of CO2 related tax rate differentiation in motor vehicle taxes 2012" <http://www2.oecd.org/ecoinst/queries/index. htm> at 5 May 2013.

200 Christian Brand, Jillian Anable and Martino Tran, above n 14.

201 Christian Brand, Jillian Anable and Martino Tran, above n 14, 146.

202 Fionn Rogan et al, above n 2, 596. 
Brand et al. (2013) $)^{203}$ advised that consideration of the wider impacts should be considered when deciding the rate of reducing in carbon emissions, and that the rate with which $\mathrm{CO} 2$ limits need to be tightened in order to keep pace with the fuel efficiency improvements, avoid net losses, and maintain public acceptance are future potential scenarios that demands consideration.

\section{$7 \quad$ Limitations addressed}

The impact of differentiated vehicle taxes have been criticized for various limitations, such the very high shift to diesel internal combustion vehicles with associated consequences for higher NOx emissions and particulates ${ }^{204}$, the potential rebound effect, and loss of government revenue ${ }^{205}$.

The focus of this paper is limited to the acquisition of new motor vehicles, and does not address other environmental externalities such as congestion, local air pollution and earmarking of revenue, which were beyond its scope. Nonetheless, it is submitted that differentiated vehicle taxes based on $\mathrm{CO} 2$ emissions apply to the acquisition of new vehicles, and it is generally assumed that buyers of new vehicles have the financial capability. Vehicle taxes will increase Australia's fleet of lower carbon emitting vehicles, which will flow through to the second hand car market and make lower emissions vehicles more readily affordable for lower income earners.

\subsection{Impact on fleet renewal}

The argument that vehicle purchase tax discourages the renewal of the vehicle fleet is not supported given that many EU Member States have had vehicle taxes since 2007, and the average age of EU passenger cars remains unchanged at 8.0 years in 2010. ${ }^{206}$ This average age is less than Australia's average fleet age of 10 years (ABS 9309.0, 2012), and none of Australia's state governments have adopted carbon differentiated vehicles taxes other than the ACT. The ACT government has a vehicle purchase tax based on each vehicle's environmental performance, and the average age of the motor vehicle fleet is eight years. ${ }^{207}$ The ACT government claims that if the current turnover of vehicle continues, then around 50 percent of the fleet will be

203 Christian Brand, Jillian Anable and Martino Tran, above n 14.

204 Robin North, Robert Noland, Washington Ochieng and John Polak, 'Modelling of particulate matter emissions from a light duty diesel vehicle' (2006) 11(5) Transportation Research: Part D: Transport and the Environment 344 - 357

205 Christian Brand, Jillian Anable and Martino Tran, above n 14, 133. The rebound effect means that an increase in fuel efficiency of a new vehicle, the marginal cost of driving is lower. The UK travel statistics show that drivers with new cars drive around 2,500km/year further.

206 ACEA, 'Vehicles In Use' (2010) European Automobile Manufacturers' Association < http:// www.acea.be/news/news_detail/vehicles_in_use/> at 2 April 2013.

207 Australian Capital Territory Government, Transport for Canberra 2012-2031 <http://www. transport.act.gov.au/_data/assets/pdf_file/0003/397245/Pages_from_EDS_ACT_Transport_ Policy_FA_final_web.pdf $>$ at 25 June 2013, 9. 
replaced by 2020; this is important in giving the ACT the opportunity to "help people choose the lowest emission new car that meets their needs". ${ }^{208}$

\subsection{Vehicle taxes biased towards more efficient diesel vehicles}

Mandell (2009) 209, and Rogan et al. (2011) ${ }^{210}$ found that the change in vehicle taxes differentiated on carbon emissions was not a switch to smaller engine sizes, but a fuel switch towards diesel. Differentiated vehicle taxes can increase market share for diesel cars, which are considered superior due to their higher fuel efficiency. In the European countries, diesel vehicle sales account for more than half of all new motor vehicle sales, and nearly 40 percent in major emerging markets such as India. ${ }^{211}$ The associated consequences of acquiring diesel cars, however, are higher NOx emissions and particulates. ${ }^{212}$ Kunert $(2007)^{213}$ proposed that the structure of the vehicle taxes should be rebalanced according to the level of $\mathrm{CO} 2$ emissions, but it should not be the sole purpose.

However, vehicle taxes have accelerated technical advancements and improvements in both diesel and petrol engines which has made the two fuel types closer substitutes. ${ }^{214}$ For instance, advances in engine technology and emission control through EURO 5 or EURO 6 have essentially forced the adoption of the diesel particulate filter and ultralow sulfur fuel, and these have nearly eliminated black carbon emissions from new light duty vehicles. ${ }^{215}$ To ensure all new vehicles meet such standards, emission bands could be extended to include a band for air pollution, such as tailpipe emission standards on diesel particulate matter. ${ }^{216}$

Further, Kok isolated the separate effects of consumer preferences and the technological advances in choosing diesel-fuelled cars, and found that these are offset by an increase in larger and heavier diesel vehicles than the average petrol

208 Ibid.

209 Svante Mandell, above n 198.

210 Fionn Rogan et al, above $\mathrm{n} 2$.

211 ACEA, "Diesel- historical series by country in Western Europe 1990-2009" (2011) European Automobile Manufacturers' Association <http://www.acea.be/news/news_detail/vehicles_in_ use/> at 2 April 2013.

Australian Capital Territory Government, “Transport for Canberra 2012-2031” <http://www.acea. be/collection/statistics $\geq$ at 16 March 2012.

212 Robin North,Robert Noland, Washington Ochieng and John Polak, above n 204.

213 Uwe Kunert and Harmut Kuhfeld, above n 84.

214 Hugh Hennessy and Richard Toll, above n 83.

215 Ray Minjares, Kate Lumberg and Sanchez Posada, "Alignment of policies to maximize the climate benefits of diesel through control of particulate matter and black carbon emissions" (2013) 54 Energy Policy 54.

216 Ibid. 
vehicles sold. This diminishes the observed $\mathrm{CO} 2$-advantage of diesel cars, and at times can mean that the diesel cars' $\mathrm{CO} 2$ advantage is worse off. ${ }^{217}$

Knittel (2011) ${ }^{218}$ and Sprei et al (2008) ${ }^{219}$ also found 56 percent of CO2 reduction from technological advances in the European Member States between 2000 and 2007 was offset by increases in larger vehicles. However, from 2008 to 2011 this effect was neutralized through monitoring the carbon emissions bands. That is, any future transition to decarbonization and electrification can be implemented through the design of vehicle taxes that can be monitored and adjusted by a combination of credits, fees, rebates, and additional tax differentiation bands to counter these problems and demand effects. ${ }^{220}$

\subsection{Rebound effect}

The rebound effect is an important consideration. The COWI Study found that the average size of vehicle in 2008 was larger than the average size in 1999/2000 because of the rebound effect that occurs when cars become more energy efficient as technology progresses. ${ }^{221}$ The enhanced energy efficiency results in greater demand for larger vehicles.

Hennessy et al. (2011), 222 and Brand et al. (2013) ${ }^{223}$ suggested that while vehicle taxation reform will increase fuel efficiency and lower driving costs, people may drive more which means the reduction in carbon dioxide emissions is only minimal. Increased vehicle travel can lead to other externalities, such as traffic congestion and tailpipe emissions. ${ }^{224}$ If these costs are high it may have important ramifications for the costs and benefits of policies to improve energy efficiency. ${ }^{225}$

217 Robert Kok, "New car preferences move away from greater size, weight and power: Impact of Dutch consumer choices on average CO2 emissions" (2003) 21 Transportation Research Part D 53.

218 Christopher Knittel, "Automobiles on Steroids: Product Attribute Trade-Offs and Technological Progress in the Automobile Sector" (2011) 101 American Economic Review 3368.

219 Francis Sprei, Sten Karlsson and John Holmberg, "Better performance or lower fuel consumption: technical development in the Sweedish new car fleet 1975-2002" (2008) 13 Transportation Research D 75.

220 Christian Brand, Jillian Anable and Martino Tran, above n 14.

221 European Commission's Directorate-General for Environment, above n 76, 95.

222 Hugh Hennessy and Richard Toll, above n 83.

223 Christian Brand, Jillian Anable and Martino Tran, above n 14.

224 David Greene, "Rebound 2007: Analysis of U.S light-duty vehicle travel statistics" 41 Energy Policy 14.

225 Carolyn Fisher and Winston Harrington, "Should fuel economy standards be tightened?" (2007) 28(4) Energy Journal 1. 
The modeling by Brand et al. (2013) 226 Peter de Haan (2009) ${ }^{227}$ and Small et al $(2007)^{228}$ suggests that the potential for consumers buying more fuel-efficient vehicles and traveling longer distances is not hugely significant However, this depends on fuel prices and real income growth.

Sorrell $(2007)^{229}$ referenced a number of international studies and concluded that the direct long-run rebound effect is likely to be less than 30 percent in the household sector, and may be closer to 10 percent for transport.

The International Energy Agency (2012) ${ }^{230}$ suggested that the rebound effects are quite low, in the order of 10 percent to 20 percent more driving for a doubling of fuel economy or halving of fuel use per kilometer. Greene $(2012)^{231}$ pointed out that the period from 1966-2007 demonstrates a rebound effect of fuel efficiency on light duty vehicle travel in the United States of 10 percent. In an earlier study, Schafer and Victor (1997) ${ }^{232}$ found that the time humans spend on mobility is relatively constant over time and over cultures.

To counter significant rebound effects, governments may choose to introduce vehicle use based policies, or increase fuel taxes as a deterrent against an increase in driving. ${ }^{233}$ Kageson (2013) ${ }^{234}$ argued that while one should be aware of the direct rebound effect, its existence is not a valid argument against investing in improved fuel efficiency.

\subsection{Carbon differentiated vehicle taxes are not regressive}

Vehicle taxes are environmental-related taxes that impose taxes on goods, which are paid for by the consumer. And clearly this imposes a heavier burden on low-income households than on high-income households.

226 Christian Brand, Jillian Anable and Martino Tran, above n 14.

227 Peter de Haan, Michael Mueller, Roland Scholz, "How much do incentives affect car purchase? Agent-based microsimulation of consumer choice of new cars- Part II: forecasting effects of feebates based on energy-efficiency" (2008) 37 Energy Policy 1083.

228 Kenneth Small and Kurt Van Dender, "Fuel effieciency and motor vehicle travel: the declining rebound effect" (2007) 28 The Energy Journal 25.

229 Great Britain, UK Energy Research Centre, “The Rebound Effect: An assessment of the evidence for economic-wide energy savings from improved energy efficiency" (Steve Sorrell, Senior Fellow UKERC) London, October 2007.

230 International Energy Agency, above n 51.

231 David Greene, above n 224

232 Andreas Schafer and David Victor, "The future mobility of the world population” (1998) 34 Transportation Research Part A 171.

233 International Energy Agency, above n 51 and Amela Ajanovic and Haas Reinhard, above n 124 refer to the use of measures such as increasing fuel taxes along with fuel intensity standards to compensate for the rebound due to the standards in detering any rebound effects of encouraging the acquisition of fuel efficient vehicles.

234 Per Kageson, 'Dieselization in Sweden' (2013) 54 Energy Policy 42. 
The arguments for removing a vehicle purchase tax is based on the premise that the price of a vehicle increases by the addition of a vehicle purchase tax, and as Katri $(2012)^{235}$ stated, the behavioral effects of this would be for consumers normally to reduce their consumption of the commodity. However, empirical evidence has shown that price responsiveness depends on the income of the households; thus, low-income households would be more responsive to price increases and more likely to reduce their consumption than higher-income households. ${ }^{236}$ In this case, the incidence of a vehicle purchase tax is less regressive, as the tax burden of low-income households would be reduced more than that of higher-income households. ${ }^{237}$ Furthermore, the carbon differentiated vehicle tax affects only those buying a new motor vehicle, and does not affect the low-income household. ${ }^{238}$

\subsection{Impact on revenue}

The objective of governments in changing the base of vehicle taxation system to $\mathrm{CO} 2$ emissions is twofold: reduce $\mathrm{CO} 2$ emissions and remain at least revenue-neutral. ${ }^{239}$

Vehicle taxes are an important revenue source for all EC Member States. On average, vehicle purchase tax and ownership taxes accounted for 1.9 percent of all revenues in $2010 .{ }^{240}$ Therefore the design of a vehicle tax system is important to national tax authorities, ${ }^{241}$ with the nature of its design possibly having a significant effect on government revenue streams. ${ }^{242}$ Therefore the aim is to design the new system with the goal of reducing $\mathrm{CO} 2$ and remaining "revenue-neutral". ${ }^{243}$

For instance, changing the vehicle purchase tax to a $\mathrm{CO} 2$ base may mean that revenue drops instantly and permanently, ${ }^{244}$ as the policy might effectively encourage buyers to choose smaller, more fuel efficient vehicles which are in a lower emissions tax band, as shown in Table 4. However, the revenue loss in changing the ownership tax to a $\mathrm{CO} 2$ base may be more gradual as car stocks adjust to the new consumer choice of fuel efficient, low emitting vehicles. ${ }^{245}$

235 European Commission, Directorate General for Taxation and Customs Union, "Regressivity of environmental taxation: myth or reality?” (Katri Kosonen), European Union, 2012.

237 Ibid.

238 Australia, ACT Government, “Green Vehicles Duty Scheme 2008” http://www.rego.act.gov.au/ assets/PDFs/Green_Vehicle_A5_brochure.pdf at April 2013.

239 European Commission's Directorate-General for Environment, above n 76.

240 Europa: European Commission Press Release: Clarifying EU rules on car taxes, 14 December 2012,

241 European Commission, Eurostat, "Taxation trends in the European Union (2012 Edition)"< http://epp.eurostat.ec.europa.eu/cache/ITY_OFFPUB/KS-DU-12-001/EN/KS-DU-12-001-EN. PDF> at April 2013.

242 W Diem, "France Cuts High-Mileage Car Bonuses, Hikes Gas-Hog Levies" (2011) Wards Auto $<$ http://wardsauto.com/ar/france_bonus_malus_111018> at April 2013.

243 Fionn Rogan et al, above n 2: 593

244 Hugh Hennessy and Richard Toll, above n 83.

245 Ibid 7065. 
In encouraging its Member States to adopt $\mathrm{CO} 2$ based vehicle taxation measures, the European Commission recommended that these measures could be designed in a revenue neutral way that would not impose an additional burden on consumers, but reward buyers of low emitting cars and penalize the purchase of less efficient vehicles. ${ }^{246}$

This was not the case in Ireland, where Hennessy et al. (2011) ${ }^{247}$ estimated that the reduction in tax revenue in Ireland would be half a billion euro per year, and unacceptable given the fiscal situation in the country. McAleer (2009) $)^{248}$ confirmed that vehicle taxation system revenue for the first half of 2009 was down by EUR 597 million compared to the same period in 2009. However, Rogan et al. $(2011)^{249}$ stated that Ireland's recession also impacted on the fall in car sales, and must be isolated in order to determine the real impact of the new vehicle taxation policy measures on the country's vehicle tax revenue. Excluding the impact of the recession, Rogan et al.'s (2011) ${ }^{250}$ modeling showed that the new tax measure had a 33 percent negative impact on revenue on the car vehicle taxation revenue, or EUR 166 million.

Feebates fiscal incentives can also have a significant effect on government revenue streams and place additional tax burdens. ${ }^{251}$ The difficulty with a feebate system is the uncertainty determining the consumer's response to the fiscal pricing incentives, which makes it difficult to determine the optimal feebate rates and timing of the tightening by emissions bands. ${ }^{252}$ However, as discussed in paragraph 5.0, "if designed carefully and adjusted over time, [it] can avoid overburdening consumers with ever more taxation whilst ensuring revenue neutrality". ${ }^{253}$ Hence, governments may need to adjust the size and timing of rebates and fees over time to ensure that the measure is economically feasible. ${ }^{254}$

\section{Australian Capital Territory's green vehicle duty scheme}

In response to the major review of Australia's Future Tax System ${ }^{255}$ in 2008 (called the Henry Review), the Council of Australian Governments (COAG) had for the first time all agreed on a comprehensive strategy to accelerate energy efficiency

\footnotetext{
246 European Commission, above n 1, para 3.1.

247 Hugh Hennessy and Richard Toll, above n 83.

248 Michael McAleer, 'State VRT falls by Euro 597m', Irish Times, 22 July 2009 <http://www. irishtimes.com/newspaper/motors/2009/0722/1224251061499.html> at 13 October 2013.

249 Fionn Rogan et al, above $\mathrm{n} 2$.

250 Ibid.

251 Christian Brand, Jillian Anable and Martino Tran, above n 14.

252 Kelly Gallagher and Erich Muehlegger, above n 85.

253 Christian Brand, Jillian Anable and Martino Tran, above n 14, 146.

254 Ibid.

255 Chaired by the former Secretary to the Treasury, Dr Ken Henry
} 
and recommended on encouraging demand for fuel-efficient low emission vehicles through reforming existing vehicle taxes by adopting differentiated charges linked to the vehicles environmental performance. ${ }^{256}$ One model recommended by COAG, was the Australian Capital Territory's (ACT) Green Vehicle Duty System (GVDS), introduced in 2008, based on the environmental ratings published in the Australian Government's Green Vehicle Guide. ${ }^{257}$ However, the final Henry Report released on 2 May 2010 opposed the proposed reform, leaving ACT as the only Australian state/territory government that had reformed its vehicle purchase taxes to provide "an incentive for the purchase of low emission vehicles and a disincentive against the purchase of vehicles with poor environmental performance." ${ }^{258}$ However, the tax design of ACT's GVDS is not as effective as the EU Member States discussed in paragraph 3.4, and will not significantly reduce emissions from passenger vehicles. Further analysis and discussion of the tax design in ACT's GVDS and the appropriateness of using the Australian Governments Green Vehicle Guide will be the basis of a subsequent paper by the author.

\section{Conclusion.}

Australia has no effective fiscal instruments to reduce road transport emissions. Further, the government has not set or legislated any ambitious targets or strong commitments in reducing road transport emissions. Instead, the government projects road transport $\mathrm{CO} 2$ emissions to be $82 \mathrm{Mt} \mathrm{CO} 2$-e by 2020, showing an increase of 51.8 per cent of 1990 levels. These emissions will then slow to no growth from 2020 to 2030 to $81 \mathrm{MtCO} 2-\mathrm{e}$, attributable to fuel efficiency improvements in conventional combustion engine vehicles, rising fuel prices, future introduction of mandatory $\mathrm{CO} 2$ emissions standards, and an accelerated take-up of hybrid and fully electric vehicles. Furthermore, the forecast is qualified on the basis that the success of technology in reducing road transport emissions is dependent on the "ability of these technologies to meet consumer needs" 259 as discussed in paragraph 2.1 .

Except consumers undervalue fuel economy and expect a high pay back period when choosing a car for fuel efficiency. Furthermore, the importance of this factor has been found to "drop-off" at the time purchase as discussed in paragraph 2.3.2. Therefore it is argued that the Australian Governments projection of slowing road transport

256 Australian Council of Australian Governments, COAG Meeting 2 July 2009, www.coag.gov.au/ node/66

257 Australia, Australian Transport Council and Environmental Protection and Heritage Council Vehicle Fuel Efficiency Working Group, "Vehicle Fuel Efficiency, Potential measures to encourage the uptake of more fuel efficiency, low carbon emission vehicles" (Australian Transport Council) Canberra, Recommendation 2.1; September 2008, 29).

258 Australian Capital Territory Government, "Summary of Actions"(2013) <http://www.transport. act.gov.au/_data/assets/pdf_file/0006/397383/Summary_of_Actions_EDS_ACT_Transport_ Policy_FA_final_web.pdf > at 16 May 2013.

259 Australian Government: Department of Energy, Resources and Tourism, "Energy White Paper 2012", above n 27, para 3.3.8. 
emissions between the period 2020 and 2030 is unlikely without the implementation of effective fiscal measures to encourage the transition to low carbon transport.

In determining what fiscal measures will most likely be effective in reducing road transport emissions, policy makers will need to recognize that rational economic theory may not necessarily apply to the acquisition of new light vehicles. This will impact on the choice of policy mix and policy design to ensure such instruments are effective in meeting the objective of reducing road transport emissions.

The paper shows that vehicle taxes reformed into an environmental tax, is a "powerful instrument" that can "drive consumer demand towards fuel efficient cars" and foster a more sustainable car market as discussed in paragraph 3.3. Car manufacturers have supported the introduction of this measure, as they are able to compete on the grounds of environmental performance, instead of having to meet consumers demand for larger and more powerful vehicles.

The ex post evidence on the successful transition to low carbon transport will require fiscal measures that provide a strong up-front price signals to influence buyers' choice of vehicle. In the case study of Ireland, the consumer response to the strong price signal at the time of purchasing a new passenger vehicle was greater than expected. That is, in the period 2007 to 2011, the weighted average of CO2 emissions of new passenger vehicles reduced by 22.7 per cent.

Thus, supporting the 2012 White Paper statement that it is the consumer's choice of vehicle that will influence the degree of acceleration to low carbon technology and the amount of carbon emission reductions. However, successful transition to lower carbon-emitting vehicles is dependent on the introduction of fiscal measures that can influence consumer choice at the time of acquisition. The advantage of reforming an existing vehicle purchase tax is that it will not be perceived to be overburdening consumers with another tax, and will most likely be politically acceptable. Although the success of the reform depends on the effectiveness of the tax design and the rate of $\mathrm{CO} 2$ tax differentiation, which must be flexible to ensure governments can assess and adjust the carbon-differentials according to the level of the transition to lower carbon vehicles and to ensure the reform remains at least revenue neutral. 